\title{
The vindication of the righteous in Romans 8:31-39: Inference and relevance
}

P J Maartens

University Durban-Westville

\begin{abstract}
This article explores the relevance and inferences of 'suffering righteousness' in the inter-textual references within Romans 4, 5 and 8 . The primary objective is to determine the contextual implications of the vindication of the suffering righteous one. The enquiry probes an analysis of the structural context and the underlying code in inter-textual references pertaining to suffering righteousness in the Psalms, Isaiah 40-55, Wisdom 2-5 and 3:6 and Macc 7:37-38, and investigates the socio-semiotic relations of references in Romans. The article takes the themes of reconciliation and justification to its logical conclusions. 'Vindication' and 'exaltation' in Romans, fulfil the structure of 'suffering righteousness' founded in the Old Testament and cognate literature. The contextual implications of 'suffering righteousness' expressed in such features as 'justification, vindication, exaltation and glorification' rectify the 'status inconsistencies' of its recipients. The variegated semiotic perspectives exercised above contribute to the polymorphous character of the meaning of the text.
\end{abstract}

\section{AIMS AND OBJECTIVES}

The purpose of this article is to determine how the vindication motif in $\mathrm{Rm}$ 8:31-39 modifies the cognitive environment of the reader and achieves relevance thereby. Relevance theory is a pragmatic linguistic theory grounded in a general view of human cognition. Sperber and Wilson (1986:V11) argue that the Principle of Relevance implies 'this fundamental idea ... that communicated information comes with a guarantee of relevance'.

* This article is adapted from a paper read at the International meeting of the SBL held at Budapest, July, 1995. My participation in the proceedings of the meeting was partly facilitated by a grant of the Centre for Science Development of the Human Sciences Research Council, South Africa. I am indebted to Dr Lydia Johnson-Hill (Centre for Constructive Theology, UDW) for her expert editing of the text and her valuable suggestions for improving the readability of the manuscript. 
According to Sperber and Wilson an assumption is relevant 'only if it has some contextual effect in that context'. Relevance is manifest in a change of the reader's cognitive environment. Let us consider te Principle of Relevance with reference to the 'cognitive environment'.

Sperber and Wilson (1986:39) explain the cognitive environment of a person as 'a set of facts that are manifest to him. To be manifest, then, is to be perceptible or inferable'. A fact is manifest to an individual, as Sperber and Wilson (1986:39) maintain, only if $s /$ he is capable 'of representing it mentally and accepting its representation as true or probably true'. 'Relevance' is achieved when the cognitive environment of the individual is changed by the least possible processing effort involved. The processing of information consists in interconnecting new information and old information. New information is information unconnected with anything in the individual's representation of the world. Old information is known information. When new items and old items of information are interconnected in the inference process further new information may be derived. The processing of new information gives rise to a multiplication effect which may be called 'relevant'. An author communicates his/her intentions to provide new information. Sperber and Wilson (1986:49) call behaviour which communicates an intention to make something manifest 'ostensive behaviour or simply ostension'. Ostension requires some further attention.

Relevance Theory regards communication to be 'ostensive' when 'a preceding context' is elucidated, qualified or even concretized. Such 'preceding contexts', relevant to $\mathrm{Rm}$ 8:31-39, may include the servant songs in Deutero-Isaiah or the suffering righteous Psalms, which will be discussed in section 4 below. 'Showing more' about the servant is Paul's way of practising 'ostensive inferential'2 communication in Rm 8:31-39. Both the significance of such possible 'previous contexts' and the new information conveyed by $\mathrm{Rm}$ 8:31-39 will merge into the encyclopedic knowledge of the reader. Sperber and Wilson (1986:15) define 'context' as the set of premises used in interpreting an utterance. The reference to 'a preceding context' requires further attention.

The preceding context refers to a set of premises alluded to by the text. In poststructural semiotics the network of references established by interacting texts may be designated as 'intertextuality'. Julia Kristeva (1984:59/60) explains intertextuality as the 'transposition of one (or several) sign system(s) into another'. It is vital for the purposes of this inquiry to determine any preceding contexts to which the text alludes and to assess its significance for $\mathrm{Rm}$ 8:31-39. The previous contexts also include earlier statements by Paul such as Rm 4:24 and 25, 5:1-11 and to a lesser degree 6:4 and 5. The aim of this article is to explicate the inferential processes starting with a set of 
premises in the text which result in a set of conclusions that follow logically from such premises. This practice is common in Biblical literature. The process of reinterpretation features frequently in midrashim which we encounter in the Old Testament and cognate literature. The present analysis will investigate how preceding contexts shape the Pauline discourse. In the context of this analysis it is equally significant to determine how Paul reinterprets the tradition of the suffering righteous one.

The term context, in Relevance Theory, also includes the context of the reader (or the exegete). Sperber and Wilson (1986:108) term the logical effects and implications relevant to the context of the reader 'contextual effects' 3 and 'contextual implications'4. Logical implications derived from the text are newly presented information. Both contextual effects and contextual implications are syntheses of old information and new information in the text. The process which synthesizes old and new information is the process of contextualisation 5 .

This interpretation includes an analysis of the structural context and the underlying codes in inter-textual references pertaining to suffering righteousness in the Old Testament and cognate literature. The socio-semiotic relations of references to the suffering righteousness in Romans will also be investigated. It is trusted that results of this study will contribute to the reconstruction and development of a new South African Christian consciousness. Contextualising 'suffering righteousness', in the discourse of $\mathrm{Rm} \mathrm{8}$, leads the reader to motifs of vindication and exaltation which fulfill the underlying codes of reconciliation and justification. The faithful community is more than mere recipients of reconciliation and justification. The vindication motif empowers the believers to become participants in facilitating the dissemination of God's grace. Stating this viewpoint contributes to a process of reconstructive theology in South Africa. A theology of reconstruction empowers the faithful community in recognition the exalted status of the vindicated servant.

Raabe (1984:77-81) derives the juxtaposition of 'themes' such as suffering/triumph, death/resurrection and humiliation/exaltation from the contrast of characteristics similar to these in Is 52:13-53:12. This article will adopt the method of juxtaposing characteristics of the suffering righteous one. The dialectical characteristics of the servant will be treated as semantic features of the suffering righteous one (servant). The semantic features which are relevant and transferred from the suffering righteous servant to Rm 8:31-39 may be written in the notational conventions of Katz and Fodor (1963) and Katz (1972:34). Such semantic features are written in parentheses. The characteristics of the suffering righteous one will be indicated by isolating semantic features such as (humiliation)/(exaltation) (suffering)/(vindication) (fidelity)/(justification) ... etcetera. 
The emphasis on (suffering) and (vindication) as correlative of (humiliation) and (exaltation) does not support the 'de-Lutheranation' (cf Watson 1986) of Pauline theology. Justification and reconciliation remain central to the discourse. It is, however, necessary to go beyond the mere traditional Lutheran interpretation of justification by faith. The inferences to be drawn logically from the tenets of justification by faith will result in conclusions articulated by such features as (thanksgiving), (triumph), (dedication), (vindication), to mention only a few.

\section{THE PROBLEM AND METHOD}

There is a tendency among exegetes following a 'code theory' to reduce the meaning of a text to a one-dimensional consciousness of the significance of the text. Form critical functionalism reduced meaning to an interpretation of the historical Sitz im Leben. Formalism and Structuralism reduce meaning to the sum-total of literary devices used in the text ${ }^{6}$. Sociological surveys reduce meaning to a consciousness of the social interaction of key role players and the early Christian community. This article attempts to surmount the limitations of functionalistic practices in Biblical interpretation.

The New Testament, as many other texts, is an artifact belonging to the category of texts which Echo (1979:49) calls an 'open text'. This characteristic becomes most apparent in Pauline diatribe which draws the reader into the dialogue. A rhetorical question such as: 'What then are we to say about these things?' ( $\mathrm{Rm}$ 8:31 also 3:1,4:1) provokes a reply from the reader. The openness of the New Testament lies in the "persuasive' character of the text. The main concern of the persuasive text is to facilitate an intended effect on the reader. Inevitably the text manifests itself as a 'writerly text.' This is how Barth (1974:4) designated texts which lead to multi-interpretability.

The method employed in this article will reflect a consciousness that knowledge of the meaning of a text is always perspectival. Although our interpretations might be relevant, they always remain relative to the limitations of the historical contingency intrinsic to the theories within which they are constituted. The expressions 'relative' and 'relevant' are juxtaposed to represent a meaningful dialectical relaition. It is conceded that our knowledge of a text, as articulated in interpretation, never exhausts the meaning of the text. The meaning of the text transcends all historical contingent interpretations. The various truth-perspectives which emanate from text interpretations enhance the polymorphous character of the meaning. Multiple interpretations result from changing historical conditions which stimulate the ongoing quest for meaning. Various perspectives of interpretations necessitate a critical dialogue responsible for verifying our findings. The findings of exegesis are confirmed or disconfirmed in theoretically constituted methods. Methodology is consequently the truth-function of our knowledge. 
The subheading 'Inference and Relevance,' in the title of the article, suggests the use of recent semiotic theory to perform the task of interpretation. Recent semiotic criticism embraces the structure of the text, the social significance and the relevance of the text. Relevance Theory is chosen because of its fundamental criticism of 'code theory' prevalent in current literary theory and interpretation. Relevance Theory does not render 'code theory' obsolete. It supplements code theory in semiotics. Relevance Theory supplements semiotic analysis because of the following inadequacies inherent to code theory:

* The gap between the semantic representation of the sentence and the meaning of the sentence cannot be narrowed by more coding but only by application of the principle of relevance.

* Attempts to interpret the relation between signifier and signified in terms of the mutual cognitive or the mutual knowledge hypothesis is doomed to failure. Interpretations sharing the same physical environment may differ from one another. Moreover, changing historical conditions and times may give rise to different interpretations. Relevance of interpretation can only be achieved in a change of the mutual cognitive environment of the writer and the reader. Relevance Theory makes the change in the cognitive environment of the writer and the reader mutually manifest. Contrary to the mutual knowledge hypothesis, it is the change in mutual cognitive environment of the writer and the reader which achieves relevance of interpretation.

In view of the reasons stated above it has become necessary to find a more convincing method of interpretation. The semiotic framework of interpretation employed in this article will include a structural perspective section 5 , a socio-semiotic interpretation section 6, and an ostensive inferential analysis in Relevance Theory section 7.

\section{THE TEXT: ROMANS 8:31-39}

To meet the requirements of a structural analysis and an inferential-semiotic analysis it is necessary to provide a sentence specification of Romans 8:31-39. This entails a demarcation of the text into sentences as syntactic units. The text of Rm 8:31-39 and other texts will be demarcated into sentences using the criteria of the 'Aspects' model of linguistic theory which defines the sentence as a syntactic unit consisting of a noun phrase and a verb phrase ( $\mathrm{S}=\mathrm{NP} \mathrm{VP})$. The further demarcation of embedded sentences may, when necessary, be numbered by a decimal point in the margin. 


\section{Sentence}

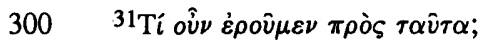

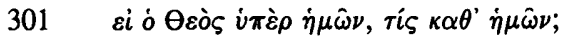

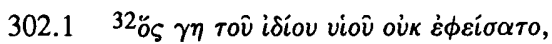

$302.2 \dot{\alpha} \lambda \lambda \dot{\alpha} \dot{v} \pi \grave{\varepsilon} \rho \dot{\eta} \mu \hat{\omega} \nu \pi \dot{\alpha} \nu \tau \omega \nu \pi \alpha \rho \varepsilon \delta \omega \kappa \varepsilon \nu \alpha \dot{u} \tau o ́ \nu$,

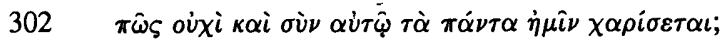

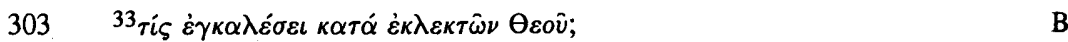

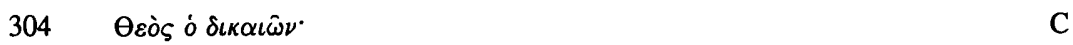

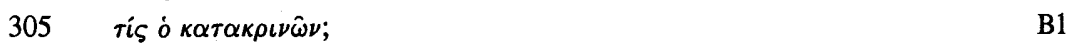

$306 \quad{ }^{34}$ X

$\mu \hat{\alpha} \lambda \lambda \circ \nu \delta \dot{\varepsilon} \dot{\varepsilon} \gamma \varepsilon \rho \theta \varepsilon i \varsigma$,

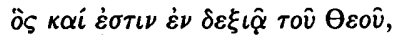

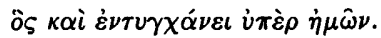

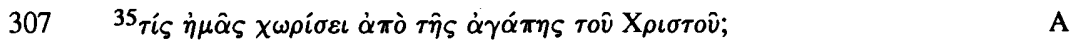

$\theta \lambda \hat{i} \psi \iota \varsigma \grave{\eta} \sigma \tau \varepsilon \nu o \chi \omega \rho i \alpha \hat{\eta} \delta \iota \omega \gamma \mu \grave{\varsigma} \hat{\eta} \lambda \iota \mu \grave{\varsigma} \grave{\eta} \gamma v \mu \nu o ́ \tau \eta \varsigma \quad$ B

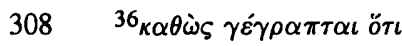

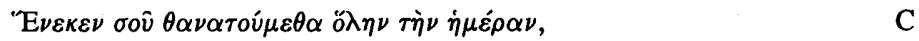

$\dot{\varepsilon} \lambda \sigma \gamma i \sigma \theta \eta \mu \varepsilon \nu \dot{\omega} \varsigma \pi \rho o ́ \beta \alpha \tau \alpha \sigma \phi \alpha \gamma \hat{\eta} \varsigma$.

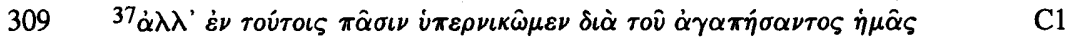

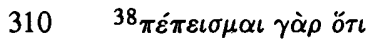

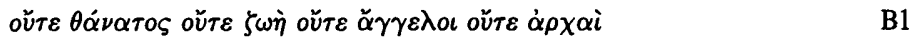

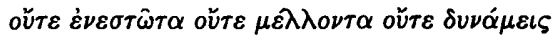

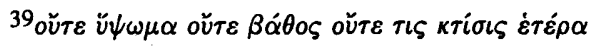

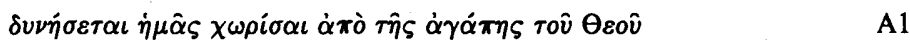

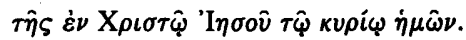

\section{INFERENCES FROM ENCYCLOPAEDIC KNOWLEDGE RELEVANT TO ROMANS 8:31-39}

In the Relevance Theory of Sperber and Wilson (1986:72), encyclopaedic knowledge is constituted by 'propositional forms (that) represent definite states of affairs.' These propositional forms reveal numerous characteristics. Propositional forms are stored in conceptual memory which can be completed into fully-fledged assumptions on the basis of contextual information. With reference to 'suffering righteousness' in Rm 8:31-39 such assumptions will be contextualised in the socio-cultural history of the Old Testament. These assumptions are propositional when in terms of Sperber and Wilson (1986:72) they are in 'logical form' and 'semantically complete.' Propositions which answer to these criteria are 'truth-preserving. 'Truth-preserving means that deductions 
made from representations of 'suffering righteousness' in the Old Testament will yield representations which are true of Romans 8:31-39. These assumptions will prove to be relevant if they 'change the cognitive environment' of the readers and consequently the readers' representation of the world.

To clarify the context which provides the assumptions that become propositional in a text, such as the text of $\mathrm{Rm} 8: 31-39$, we may also refer to the structural explication of Weinrich (1967). Weinrich (1967:6) calls a set of assumptions which provides a contrasting context to interpret another text a 'counter-determining context.' It is consequently necessary to elucidate some of the attributes of 'the suffering righteous one' as the counter-determining context of $\mathrm{Rm} 8: 31-39$. The choice of suffering righteousness as a counter-determining context for $\mathrm{Rm}$ 8:31-39 recognizes the 'suffering righteous one' (/servant) as the metaphorical referent of Rm 8:31-39. Intertextuality provides a useful framework to allow for the interaction of semantic features of suffering righteousness and the text of Romans 8:31-39. On the basis of these criteria the following aspects of the suffering righteous one (or servant) are relevant for Rm 8:3139.

\subsection{The counter-determining context of symbolism}

Kleinknecht (1981) provides a comprehensive description of the counter-determining context of suffering righteousness. Kleinknecht summarizes the conventions of the suffering righteous as follows:

Mit grosser Wahrscheinlichkeit sind die ältesten greifbaren Texte vom 'Leiden des Gerechten' kultische Gebrauchstexte gewesen, deren Function es war, die durch (Feind-) Bedrängnis gestörte zedekah-Beziehung des Beters zu Jahwe durch einen zedekah-Erweis Jahwes wiederherzustellen. Dieser Erweis wurde in der kultischen Situation unmittelbar erwartet. Der jeweilige Beter trat dabei in das kultischen Urbild des zadi'k ein, das in den verschiedenen Psalmen durch Parallelbegriffe verschiedener Nuancierung konkretisiert fund akzentuiert wird.

(Kleinknecht 1981:25)

Peach (1977b:off) and Kleinknecht (1981:18) consider, among other references, the following Psalms as relevant for the conventions of the suffering righteous one: 3,5 , $6,7,13,18,22,26,27,28,30,31,35,41,43,44,49,54,56,57,59,64,69,80$, 
$89,109,110,118$ and 142. The Psalms and cognate literature such as Wisdom 2-5, Macc 7:37-38, 4 Ezra 13, Isaiah 40-55 and the Similitudes of Enoch 37-71 provide a framework of intertextuality on which the figure of the suffering righteous one depends. Rm 8:31, 34 and 36 allude to $P s$ 118:6, 110:1 and 44:23 respectively.

The most significant features of suffering righteousness, relevant for $\mathrm{Rm}$ 8:31ff, are evident in the juxtaposition of the themes of (humiliation)/(exaltation ${ }^{7}$ ), (suffering)/(vindication $\left.{ }^{8}\right)$, (death)/(resurrection) and (faithfulness $\left.{ }^{9}\right)$ and $/($ justification). The independent tradition of the Gospels enhances these features. Goppelt (1975:240) derives this tradition from the historical Jesus:

So war es wohl von Jesus selbst angeregt, wenn die Passionsgeschicte in laufender Anlehnung an die Psalmen von leidenden Gerechten dargestellt und ausgestaltet wurde.

The freshness of expression in the Beatitudes Mtt 6:3-12 would, judged by the criterion of dissimilarity, seem to support the viewpoint of Goppelt. Paul is certainly employing an old theme which he encountered in the Palestinian Christian tradition.

Characteristics of the suffering righteous one available from the reader's encyclopaedic knowledge of the Old Testament and cognate literature may be represented in the following set of semantic features: (humiliation) (obedience) (faithfulness) (fidelity) (exaltation) (elect) (trustworthiness) (vindication) (justification).

\subsection{The tenor or principle subject of the suffering righteous one in Isaiah 52:13- 53:12}

In Is 52:13-53:12 the suffering righteous one merges with the suffering servant into a single context. Paul sometimes reserves the suffering servant exclusively for Jesus, as in the context of Phil 2:4-11. In Phil 2:4-11 Jesus is more than the suffering righteous one. Jesus is the servant! In Rm 8:31-39, however, Paul merges the imagery of the suffering righteous one (S.308-310) and the suffering servant (S.302-306).

The vehicle 'servant of Yahweh' in Is $42: 19 \mathrm{~b}$ is a complex metaphor which resembles Brooke-Rose's (1958:40) category of 'compound metaphors'. The noun ebed, in construct state, is the metaphoric term. The metaphor may more particularly be classified among the metaphors exhibiting a 'three term formula' which may be represented as $\mathbf{A}=\mathbf{B}$ of $\mathbf{C}$. The third term $\mathbf{C}$ represents the metaphoric term $\mathbf{B}$ in one aspect only. It attributes one semantic feature, e $\mathrm{g}$ (divine), to the metaphoric term servant. The metaphor expresses the divine purpose with Israel. God saves Israel but also intends using Israel as 'light for the nations' (cf Is $42: 1 \mathrm{ff}$ and $49: 1 \mathrm{ff}$ especially verse 6). Soon the prophet realizes that Israel would suffer to attain this goal. Vriezen (1966:77) sig- 
nifies the theme of suffering as a fresh development in the exile. It occurs in Is 50:4ff and fully manifests in Is 52:13-53:12. Vriezen (1966:81) further shows that prior to the exile the theme of suffering only appears in Zech 12:10. The vehicle: 'servant of Yahweh' refers to three distinct principal subjects respectively:

\subsubsection{A Jewish leader or Israel as tenor}

The metaphoric term may, when used in the singular, possibly refer to Israel (or Jacob) or an individual leader of Israel. In any event the metaphoric term 'my servant', in Is 52:13 and 53:11, is a submerged metaphor because the actual referent is never mentioned in the context. Deist (1985:5) interprets the song as a Deuteronomistic midrash on Moses as prophet of the exodus. The person of Moses is the counter-determining context which provides a paradigm for the servant. Is 52:13-53:12 reinterprets the servant in language reminiscent of the Mosaic exodus. The terminology will, however, also exceed the exodus motif. Deist identifies the tenor as the exilic community. Watts (1988:119) shows that in the singular the tenor may either be Israel, as in Is 41:8, or (p119) Jacob as in Is 44:1. Beuken (1979:119 and 130) concurs with this interpretation. Watts (1988:119) shows that in Is 48:16-20, Sheshbazzar is the most probable tenor. In the case of Is 53:1-6 and 11-12, Watts (1988:117 and 178) identifies Zerubbabel as probably the tenor. The theme of suffering articulates the ministry and subsequent sudden disappearance of Zerubbabel. At this point the introduction of vicarious and substitutionary death comes as a new development. Suffice it to say that the servant, as vehicle, is counter-determined in Deuteronomistic characteristics reminiscent of a prophet like Moses. The language also exceeds the mere symbolism of the exodus. Both the exodus and the conquest become relevant to the symbolism. The characteristics of conquest are manifest in features of (vindication) (glory) and (victory) evident in Is 53:12. The metaphor transfers such semantic features as (vicariousness ${ }^{10}$ ) (mortality) (suffering) (atonement) (liberation) (salvation) to 'the servant' as tenor of the vehicle in Is 52:13 and 53:11.

\subsubsection{A non-Jewish leader or Yahweh as tenor}

The metaphoric term may when used in the singular refer to non-Jewish leaders. The 'actual referent' in this case is, according to Watts (1988:117), the conqueror whom Yahweh called from the east to accomplish His will. Deutero-Isaiah clearly shows disappointment with Jewish royal symbols. The 'servant of Yahweh', as compound metaphor, sets up a chain of references which circumlocutes Jewish royal designations. In Is $44: 28$ the servant is 'the shepherd', in 45:1 'the anointed' and in 43:20 and 45:4 'the elect' or. 'the chosen one'. Beuken (1979 11A:131) indicates that he may even be a 'new Moses': In Cyrus, Darius and Artaxerxes, however, the reader recognizes cha- 
racteristics of the servant. In Is $44: 28 ; 45: 1$ and 13 ; and $48 ; 15$, as Beuken (1979 $11 \mathrm{~A}: 130)$ shows, Cyrus is the principal subject. In the context of Is $49: 5-6 ; 52: 13$ and 53:11 Darius may also very possibly be the 'principal subject' referred to. The ambiguity surrounding the tenor as actual referent clearly illustrates the polymorphous character of interpretation.

Swartley (1994:56) draws attention to the fact that the theology of exodus affirms not Moses, but Yahweh as the actual Liberator. In the royal servant songs, above, Yahweh is the Warrior who triumphed gloriously as $\mathrm{He}$ did in the words attributed to Moses in Exod 15:1-3. Deist provides independent confirmation by showing the appropriation of the theme of Yahweh as warrior in Deutero-Isaiah, especially Is 42:13-17. Swartley (1994:115) continues to show that 'God's victory comes in a most unsuspecting way: the way of self-denial, humble service and the giving of one's life for others'. This way does not simply lead to death or suffering, but constitutes the way to God's victory. Deist (1985:3) continues to show how the new way through the desert would be like a highway prepared for a king e $\mathrm{g}$ Is $40: 3$ and 43:19. In this context the following semantic features become relevant for the servant: (suffering11) (substitutionary) (vicarious) (intercession ${ }^{12}$ ) (anointed) (conqueror) (victor) (elect ${ }^{13}$ ) (legitimacy ${ }^{14}$ ) (integrity) (righteousness ${ }^{15}$ ) (deliverance ${ }^{16}$ ) (liberation) (salvation) (universal ${ }^{17}$ ) $\left(\right.$ peace $^{18}$ ).

\subsubsection{The remnant as tenor}

The metaphoric term may when used in the plural refer to the faithful as 'servants of Yahweh.' Such references may be found in Is 54:17 and 65:8-16. The 'actual referent' may be the pious worshipers who, as Watts (1988:117 and 224) indicates, are simultaneously the chosen people of Yahweh. Trito-Isaiah, (compare Is 65:8) reinterprets the "remnant of Yahweh" in Deuteronomistic language as the victorious servant. Features such as (elect) (anointed) (true Israel) (triumph) (glory) are descriptive of this category. This category is most relevant for $\mathrm{Rm} 8: 31 \mathrm{ff}$.

\section{STRUCTURAL PERSPECTIVE ON ROMANS 8:31-39}

\subsection{The preceding contexts relevant to Romans 8:31-39}

The text of $\mathrm{Rm} 8: 31-39$ correlates linguistically with the text of $\mathrm{Rm} 4: 23-25$ and $\mathrm{Rm}$ 5:1-11. Both $\mathrm{Rm} \mathrm{4:23-25}$ and $\mathrm{Rm}$ 8:28-30 are "previous contexts' alluded to in $\mathrm{Rm}$ 8:31-39. 


\subsubsection{Romans 4:23-5:11 as preceding context}

$\mathrm{Rm}$ Sentences

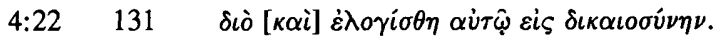

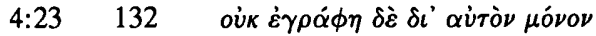

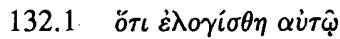

4:24 $133 \quad \dot{\alpha} \lambda \lambda \grave{\alpha} \kappa \alpha i \iota^{\prime} \dot{\eta} \mu \hat{\alpha} \varsigma$

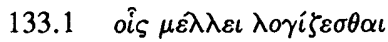

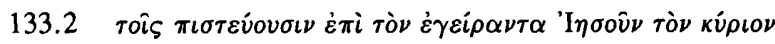
$\dot{\eta} \mu \hat{\omega} \nu \dot{\varepsilon} \kappa \nu \varepsilon \kappa \rho \hat{\omega} \nu$

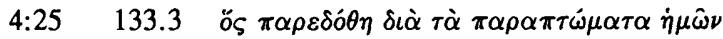

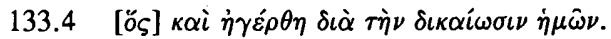

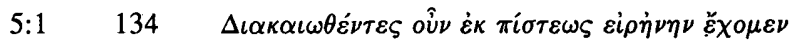

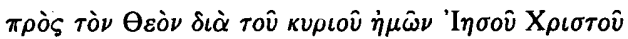

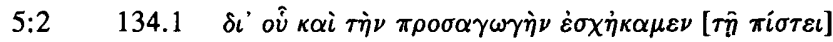

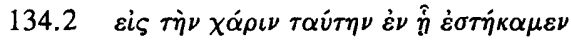

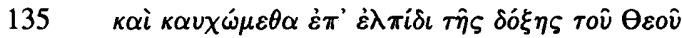

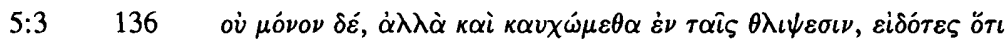

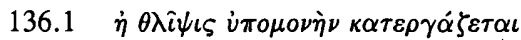

5:4 $136.2 \quad \dot{\eta} \delta \grave{\varepsilon} \dot{v} \pi \circ \mu \circ \nu \grave{\eta} \delta o \kappa \iota \mu \dot{\eta} \nu$, (deleted: $\kappa \alpha \tau \varepsilon \rho \gamma \alpha \dot{\alpha} \zeta \varepsilon \tau \alpha \iota)$

$136.3 \dot{\eta} \delta \dot{\varepsilon} \delta o \kappa \iota \mu \grave{\eta} \dot{\varepsilon} \lambda \pi \iota \delta \alpha \cdot$ (deleted: $\alpha \alpha \tau \varepsilon \rho \gamma \dot{\alpha} \zeta \varepsilon \tau \alpha \iota)$

5:5 $137 \quad \dot{\eta} \delta \dot{\varepsilon} \dot{\varepsilon} \lambda \pi i \varsigma$ où $\kappa \alpha \tau \alpha \iota \sigma \chi \dot{v} \nu \varepsilon \iota$,

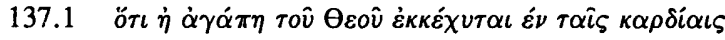

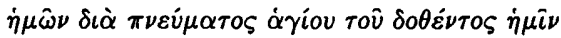

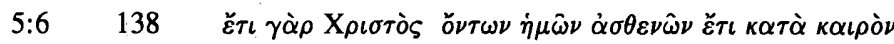
$\dot{v} \pi \dot{\varepsilon} \rho \dot{\alpha} \sigma \varepsilon \beta \hat{\omega} \nu \dot{\alpha} \pi \varepsilon \dot{\varepsilon} \theta \alpha \varepsilon \nu$

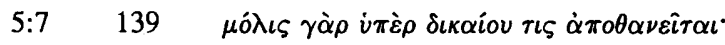

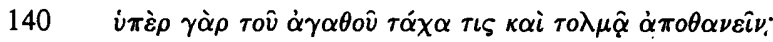

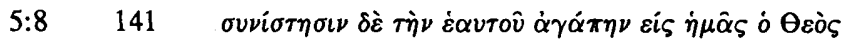

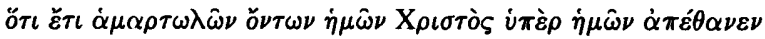

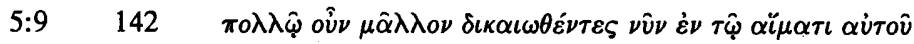

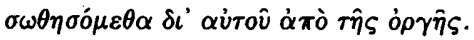

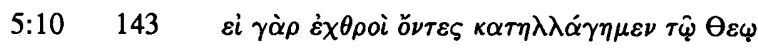

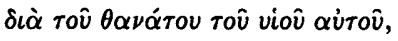

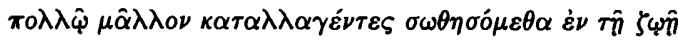




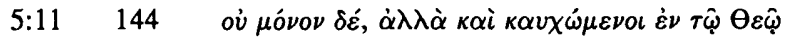

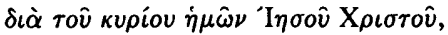

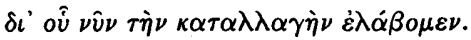

The formal method of textual analysis provides the exegete with a valuable frame work to articulate the particularization of imagery, contrastive and correlative language usage

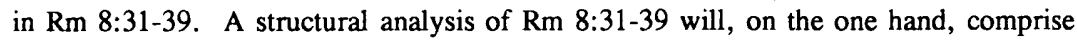
an analysis of the correlative language usage in the text. On the other hand, a structural analysis will be adequate to provide a descriptive analysis of the juxtaposition of the themes exaltation/humiliation in the text of $\mathrm{Rm} 8: 31-39$.

\subsubsection{The correlative language usage in Romans 8:31-39 and 4:22-5:11}

The correlative language usage evident in themes common to $\mathrm{Rm} 5$ and $\mathrm{Rm} 8$ is well documented in the encyclopaedic knowledge preserved in commentaries on Romans. The correlation of major themes demarcates chapters $5-8$ as a unit within the Epistle to the Romans. The inclusio which these themes establish provide this inquiry with a framework within which to analyze the significance of the suffering righteous one in $\mathrm{Rm}$ 8:31ff. The following examples will suffice:

* The term $\dot{\varepsilon} \lambda \pi i \varsigma$ in both $\operatorname{Rm~5:5,~which~reads~'hope~does~not~disappoint~us',~and~}$ $\mathrm{Rm}$ 8:24, which reads 'For in this hope we were saved', are ostensive inferential terms: 'E $\lambda \pi i \varsigma$ replaces and qualifies $\pi i \sigma \tau \iota \varsigma$ in both contexts. In Rm 8:24 'hope' contrasts $\pi \alpha \theta \dot{\eta} \mu \alpha \tau \alpha$ (verse 18) just as it contrasts $\theta \lambda \hat{\imath} \psi \iota \varsigma$ in sentences 136 and 136.1. In verse $24 \dot{\varepsilon} \lambda \pi i \varsigma$ is used in an 'additive' context with eschatological significance.

* The term $\dot{\alpha} \gamma \dot{\alpha} \pi \eta$ in $\mathrm{Rm}$ 5:5 recurs in $\mathrm{Rm} \mathrm{8:35}$ and 37. The term love completes the famous Pauline triad faith, hope and love. In the context of $\mathrm{Rm}$ 5:6-8 divine love is unconditional love. In $\mathrm{Rm} \mathrm{8:35}$ and 37 love is victorious. In $\mathrm{Rm} \mathrm{8:35}$ and 37 the subject of love reaches fulfillment.

* In both $\mathrm{Rm}$ 5:8 and $\mathrm{Rm}$ 8:32 the love of God is made manifest in delivering Jesus for us all. Divine love is love which sacrifices. It is unconditional and seeks no merit in the object of its love. It links 'the righteous ones' inseparably to God. It is triumphant. In $\mathrm{Rm} 8: 32$ the expectations of the previous contexts in $\mathrm{Rm} 5: 5-8$ are fulfilled. 
* Both $\mathrm{Rm} 5$ and $\mathrm{Rm} 8$ preserve the prerogative of divine initiative. In $\mathrm{Rm} 5: 1$ and 11 and $\mathrm{Rm} \mathrm{8:6}$ and 30 God justifies and bestows peace on the righteous. In $\mathrm{Rm}$ 5:8 and $\mathrm{Rm}$ 8:30 God manifests his love by delivering Jesus for us all. The Spirit is the author of life ( $\mathrm{Rm} \mathrm{8:11)}$ and bestows love on the faithful ( $\mathrm{Rm}$ 5:5). In $\mathrm{Rm}$

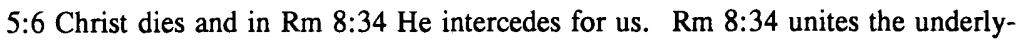
ing themes of death, resurrection and intercession.

* $\mathrm{Rm} 8: 10,18$ and 34 reiterate the juxtaposition of death/resurrection, suffering/vindication and humiliation and glorification which occurs emphatically in $\mathrm{Rm}$

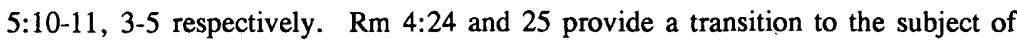
death and resurrection: 'It will be reckoned to us who believe in him that raised from the dead Jesus our Lord, who was put to death for our trespasses and raised for our justification'.

The correlative language usage in $\mathrm{Rm} 5$ and 8 leads us to conclude that Chapter 8 particularizes and fulfills the structure and expectations of Rm 5. It is particularly the juxtaposition of themes expressed by semantic features of (suffering)/(vindication), (life)/(death), (humiliation)/(exaltation) with emphasis on victorious living and glorification that compels us to look more closely at the vindication of the suffering righteous one in $\mathrm{Rm} 8$.

\subsubsection{Romans 8:28-30 as preceding context}

Two expressions allude to the suffering righteous and introduce the image into the context of $\operatorname{Rm} 8: 31-39$. These references are the following expressions of verses 28-30:

$\mathrm{Rm} \quad$ Sentences

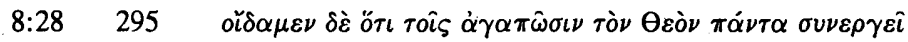

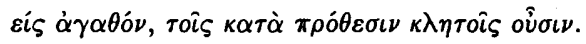

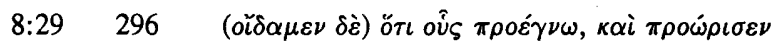

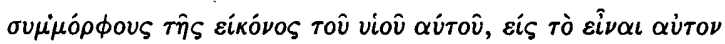

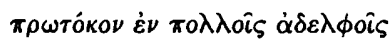

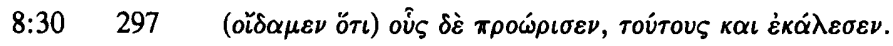

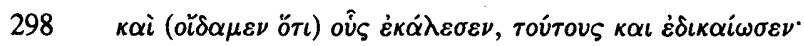

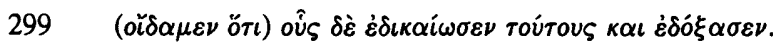


The following themes of the text are relevant for the interpretation of $\mathrm{Rm}$ 8:31-39.

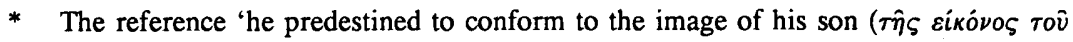
vioû $\alpha$ vitov̂)' presupposes the suffering and resurrection of Jesus. This assumption

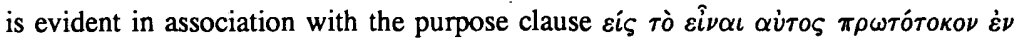
$\pi 0 \lambda \lambda \circ \hat{\imath} \varsigma \dot{\alpha} \delta \varepsilon \lambda \phi o i \varsigma$. A parallel statement in Col 1:18 elucidates this expression: ' $\mathrm{He}$ is the head of the body, the church; he is the beginning, the first-born from the

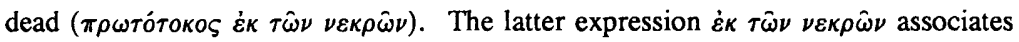
$\pi \rho \omega \tau$ т́локо $\varsigma$ with the suffering of Jesus. He is the first to emerge superior from the dead. The references in Rm 8:32 to 'God did not spare his own Son but gave him up for us all' and 8:36 'we are being killed all day long; $\ldots$ as sheep to be slaughtered' reinforce the suffering motive. The $\pi \rho \omega$ тóroкos particularizes the suffering righteousness of the servant. Cranfield (1975:432) comments that it expresses 'the unique pre-eminence of Christ and the fact that $\mathrm{He}$ shares His privileges with His brethren'. The faithful conform to his suffering and obedience which leads to justification and glory. Suffering righteousness is further evident by the election of the faithful who are 'predestined to conform to the image of his son'.

* The second significant reference to suffering righteousness in the context becomes evident in verse 30 . The expression 'he predestined', in sentence 297 , designates the 'chosen one' or 'the elect one'. The language usage is reminiscent of the suffering righteous one. Section 4.2.2, and note 13, above designate (election) as a semantic feature of the servant. The verbal phrase 'he called' stands in a causal relation to 'predestined'. The causal relation particularizes in the humble submission of the suffering righteous one. Righteousness, as indicated in section 4.1, note 9 above, manifests in faithfulness to the divine call. Faithfulness correlates with justification. The righteous one is justified by God. The verbal phrases in verse 30 particularize the juxtaposition of suffering and vindication. Those whom God justifies he consequently also glorifies.

The climax, in verse 30, coupled with reference to the $\pi \rho \omega \tau$ тотоко , in verse 29 , merges with the encyclopaedic knowledge of the suffering righteous one to reinforce semantic features such as (humiliation)/(exaltation), (suffering)/(vindication) (death)/(resurrection), (faithfulness)/(justification) and (righteousness)/ (glorification). These features are ready to be contextualised in $\mathrm{Rm}$ 8:31-39. 


\subsection{The structure of Romans 8:31-39.}

Extra patterning in sentences 300-310 exhibits a 'double parallelism' in Jakobson's (1960:412) terms. The parallelism is introduced by two rhetorical questions: S.300: 'What shall we say about these things?'; and S.301: 'If God is for us who is against us (N R S V)?' The questions have illocutionary force. They elicit the reply: 'No one is against us'. The implicit conclusion: 'we are victorious,' becomes apparent. The rhetorical questions are followed by two parallels in section 5.2.1 and section 5.2.2.

\subsubsection{The vindication of the servant}

Sentences 302-306 constitute a unit. This unit arranges itself chiastically around sentence 304 which is the focal sentence of the first unit. The focal sentence, S.304, asserts God as judge of humankind: 'It is God who justifies' (N R S V). The chiasm may be presented as follows:

A The verbs $\dot{\varepsilon} \phi \varepsilon i \sigma \alpha \tau o$ (S.302.1) and $\pi \alpha \rho \varepsilon \delta \omega \kappa \varepsilon \nu$ (S.302.2) portray the motif of the suffering servant. The language is reminiscent of the language of Gen 22. The verbs emphasize divine initiative in the sacrificial offering. The question: 'How will he not give us all things with him?' appropriates the redemption facilitated by the servant for the faithful community. The pronouns $\dot{\nu} \pi \grave{\varepsilon} \rho \dot{\eta} \mu \hat{\omega} \nu$ and $\dot{\eta} \mu \hat{\imath} \nu$, in S.301/2, particularize in the context and allude to the vicarious suffering of the servant in S.301-310, as a unit.

B Sentence 303 introduces forensic language. The rhetorical question, 'Who shall bring any charge against God's elect?', merges the imagery of the 'suffering servant' and 'the suffering righteous one'. The expression $\dot{\varepsilon} \kappa \lambda \varepsilon \kappa \tau \hat{\omega} \nu$ $\Theta \varepsilon o \hat{v}$ designates the servant as indicated in section 4.2 .2 , note 13 . The divinely elected servant is beyond indictment. The expression $\dot{\varepsilon} \kappa \lambda \varepsilon \kappa \tau \hat{\omega} \nu \theta \varepsilon o \hat{v}$ in $\mathrm{S} 303$ is not ambiguous. The $\dot{\varepsilon} \kappa \lambda \varepsilon \kappa \tau \hat{\omega} \nu$ (plural) refers to the faithful community as servant. This assumption is clear from the comment in \$306 that Christ 'intercedes for us'.

C Sentence 304 asserts God as the judge of humankind. It is God who justifies the righteous. This comment is the focal sentence of $\mathbf{S 3 0 0 - 3 0 6}$ as a unit.

B1 Sentence 305 retroactively strengthens sentence 303: 'Who is to condemn?'. It balances the question in S303: 'Who will lay charges against God's elect ones?' The rhetoric reinforces the presupposed righteousness of the servant. The imagery of the servant and 'the suffering righteous ones' continue to merge. 
A1 Sentence 306 asserts the suffering of Jesus in concrete terms: 'It is Christ Jesus who died, moreover who rose'. The statement juxtaposes the death and resurrection of Jesus as servant. As resurrected Lord at the right hand of God, He intercedes for us. With God as judge and Christ as our advocate who can calumniate the righteous one?

The double parallelism transfers the subject of vindication to the faithful community as 'the righteous one' in sentences 307-310. The vindication of the 'righteous one' completes the symmetry in the double parallelism.

\subsubsection{The vindication of the righteous ones}

Sentences 308-310 are a unit. This unit arranges itself chiastically around sentence 309 which is the focal sentence of the parallelism. The focal sentence emphasizes the vindication motif: 'In all these things we are more than conquerors through him that loved us'. The chiasm may be presented as follows:

A The rhetorical question in sentence 307 asserts the uniqueness of the love of Christ: 'Who will separate us from the love of Christ?'. The latter phrase repeats in S310. In S310 'the love of God' substitutes the love of Christ in S307. The repetition of the phrase establishes an inclusio.

B The continuation of the question in sentence 307 focalises the discourse on conditions which provide the contexts of suffering. Conditions of hardship, or distress, or persecution, or famine, or nakedness, or peril, or the sword threaten to separate us from God.

C Sentence 309 is an elaboration on the otherwise symmetrical structure which shapes the Pauline discourse from the Old Testament tradition of the suffering righteous servant taken from Ps 44:22 and Is 53:7. The mood of the utterance is determined by cultic language of submission, sacrifice and death.

C1 Sentence 310 introduces the antithesis contrasting the suffering and humiliation of the servant: 'No, in all these things we are more than conquerors through him who loved us'. This statement vindicates the suffering righteous.

B1 Sentence 311 concludes the antithetic parallelism. Verse 38 shifts the focus to agents of suffering. These agents consist of death, life, angels, principalities, height and depth. 
A1 Verse 39 reiterates that neither these agents of suffering nor anything else in all creation will be able to separate us from the love of God which is in Jesus Christ. The expression $\dot{\alpha} \gamma \dot{\alpha} \pi \eta \varsigma$ rôे $\theta \varepsilon o \hat{v}$ is in syntagmatic equivalent position with

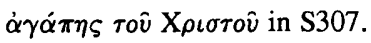

\subsection{Resume and critique}

Section 5.2, 1-5.2.2, above provides a descriptive analysis of the text of $\mathrm{Rm} 8: 31-39$ which applies the code theories inherent to Prague Structuralism. A code, as Sperber and Wilson (1986:3) explain is a system which pairs messages with signals. 'A signal', Sperber and Wilson (1986:4) continue to explain,' 'is a modification of the external environment which can be produced by one device and recognized by another'. The message is 'a representation internal to the communication device'. The application of the codes provided by Prague structural analysis produced the following results:

* The antithetical parallelism in sentence 300-306 foregrounds Jesus as eschatological mediator of humankind. The parallelism focuses on God as Judge. The antithesis contrasts accusation/acquittal, death/resurrection, suffering/vindication and condemnation/ justification applied to the servant.

* The synthetical parallelism in sentence $307-310$ foregrounds the vindication of the righteous one. The parallelism appropriates the victory of the servant (section 5.2.1) for the faithful community. The triumph of grace becomes the triumph of faith. The faithful are more than conquerors.

Structuralism, by analysis of the codes, does provide clues to the author's intentions, but is inadequate to explicate meaning. Meaning comprises more than intentions. It is the fulfillment of intentions that are significant for interpretation. Jauss (1982:16) is adamant about the fact that meaning is not the sum-total of structural devices in the text. A formal analysis results in a one-dimensional structural consciousness of the text. The Pauline text is an 'open text' and as 'writerly text' it facilitates multiple possibilities of fulfillment.

The greatest shortcoming of structuralism lies in the basic assumption of the common knowledge or mutual knowledge hypothesis which is central to the code theory of communication. Communication is only possible if the sender and the recipient have common knowledge of the code. Sperber and Wilson (1986:16) convincingly contend that human knowledge 'tends to be highly idiosyncratic'. Differences in life history, context, cognition and memorized information produce differences in outlook on 
reality. Even two individuals sharing the same physical environment will hold different views on it. Sperber and Wilson (1986:21) conclude that 'the mutual-knowledge hypothesis is untenable'. Human cognition is historically and culturally conditioned. Logical form is propositional. Human cognition is truth-preserving and perspectival. Relevance Theory substitutes mutual knowledge by 'mutual cognitive environment'. Meaning becomes manifest in a change of the mutual cognitive environment.

Structuralism is an immanent text analytical process. It is a self-focusing text referential system. At most it provides an interpretation of the text as literary device. The structural perspective needs to be contextualised in the encyclopaedical knowledge of the text. To safeguard structural interpretation from the sterility of functionalism we have to contextualise a structural analysis in the socio-historical context of our knowledge of the text.

\section{A SOCIO-SEMIOTIC READING OF ROMANS 8:31-39}

Meeks (1982) pioneered research into the composition of Christian communities which Paul served. The Pauline communities were a microcosm of Hellenistic society comprising the poor and dispossessed, slaves and freedmen. Some more 'wealthy' members of the community may have enjoyed a relatively high social standing. They were all expelled from Rome in $49 \mathrm{CE}$ and possibly returned when Claudius died, or shortly before, in 54 CE. They all had reason to be discontented with the Roman authorities ( $\mathrm{Rm} 5: 1-7)$. It is quite possible that the noun $\theta \lambda \hat{\imath} \psi \iota \varsigma$ in the expression 'suffering produces endurance', in sentence 3, refers to this time. Their social status could perhaps best be described as that of 'returning exiles'. After $54 \mathrm{CE}$ the majority of these people were 'upwardly mobile'. Meeks further carefully analyses the assumptions and beliefs which integrated this community and which provided it with some social cohesion.

Meeks enumerates many beliefs important to if not unique to early Christianity. Among these beliefs Meeks (1982:271) regards the death and the resurrection of Jesus as the decisive events that united the community. Sentence 8 contains for Meeks the fundamental claim of the Gospel: 'But God shows his love for us in that while we were yet sinners, Christ died for us'. The juxtaposition of the death and resurrection frequently occurs in statements like: 'Christ Jesus who died: indeed who was raised' ( $\mathrm{Rm}$ 8:34a also 4:25). Meeks (1982:272) shows how this juxtaposition gives rise to a pattern of statements in antithetic parallelism that occurs again and again in Paul's letters, especially in $R m$ 3:21-26, 5:9 and 10, 6:5-11 and 10:9. The juxtaposition of the death and resurrection necessitates consideration for the social significance of both events as contrasted in an antithesis. 


\subsection{The cross and resurrection as symbol of reversal}

It is possible to distinguish some social functions of the crucifixion in early Christian communities. Highlighting these will contribute to our understanding of the social significance of the event. The social significance of the Christ event also embraces the resurrection. After the Damascus encounter nothing would remain unchanged. The resurrection established a 'reversal principle' which permeates the discourse in the epistle. In Rm 8:31 Paul resorts to the $\dot{v} \pi \grave{\varepsilon} \rho \dot{\eta} \mu \hat{\omega} \nu$ formula to express the vindication motif: 'If God is for us who can be against us'. We encounter the 'reversal principle' in similar rhetorical dialectics juxtaposing opposites like 'for' and 'against'.

Barton (1982:14) argues persuasively that the cross became the 'symbol of reversal' which provided supporters with access to an 'alternative source of power'. As 'symbol of reversal' the cross constituted an 'inversion of the spiritual and moral ideas and institutions of Paul's day: it turned upside down notions of honour and shame'. This observation is evident in $\mathrm{Rm} 8: 32$, 'He who did not withhold his own Son, but gave up for all of us, will he not with him also give us everything else?' The principle of reversal poses a challenge to all levels of imperial and judicial council of both Roman or Jewish legislation: $\mathrm{Rm} 8: 33$, 'Who will bring any charge against God's elect? It is God who justifies. 34, Who is to condemn? It is Christ Jesus, who died, yes, who was raised, who is at the right hand of God, who intercedes for us'. The 'principle of reversal' elevates the (humiliated) to levels of (exaltation), vindicates the (suffering) in (triumph), replaces the (guilt) of the faithful by (justification), conquers (defeat) in (victory) and limits the rule of death by the power of the resurrection. The 'principle of reversal' thus enhances the incomparability of God's grace.

A significant number of the people who were converted to the Christianity of the Pauline circle had experienced ambiguities in their social status. Many of the prominent members of the Pauline communities suffered from what Meeks (1982:268) designates as 'high status inconsistency' or alternatively 'low status crystallization'. 'Status inconsistency' manifests itself in communities where people who are upwardly mobile achieve a social status higher than their attributed status. Some scholars like $\mathrm{L}$ Alexander (1986:70) embraced the hypothesis. Many scholars expressed reservations to some degree ${ }^{19}$. Holmberg (1990:130-134) gives it the academic status of being only an interesting proposal. All those who suffer 'low status crystallization' are given their rightful place in the community. Paul was allegedly himself a victim of 'status inconsistency'.

Stephen Barton (1982:14) concurs with Malherbe (1977) and Hock (1980) in calling for a consideration of the 'social realities of Paul's situation'. He supports Holmberg (1978) who claims that Paul, as a leader, was both in a position of authority 
and was recognized as one having power. His authority, however, was not unlimited or universally recognized. Barton (1982:14) indicates that Paul's authority was limited primarily by the authority of the Jerusalem church and possibly also by personal inadequacies. The encounter with the resurrected Lord who was crucified became Paul's 'source in tradition' which put him on a par with the leaders in Jerusalem. Rm 5:3-5 comments on the 'reversal of values': 'suffering produces endurance, endurance produces character and character hope'. The 'reversal symbol' represented by the cross empowered the supporters of Paul to surmount their 'status inconsistencies'. The strengthening of the positions of the followers of Paul would also allegedly enhance his own position of authority.

It was probably mostly the powerless of the lower socio-economic strata of the Greco-Roman society that were affected. For the powerless the symbol of the cross must have been very potent. The cross gave them access to an alternative source of power' based on a theology that taught that the first would be last and the last would be first.

Gal 3:27-28 makes provision also for women rendered powerless in the GrecoRoman society. Women saw a reversal in their status which rendered them positions of prominence rather than positions of subordination. Barton (1982:17) observes that the cross provided the common ground for an individual and communal identity which diametrically opposed the social classifications of the times.

Meeks (1982:273) attributes the talk of suffering and persecution to the social function of enhancing group solidarity by emphasizing the dangers from without. In this way the converts are given powerful models of the endurance of suffering, as in $\mathrm{Rm}$ 5:3 and $\mathrm{Rm}$ 8:35-36. (38) 'For I am convinced that neither death, nor life, nor angels, nor rulers, nor things present, nor things to come, nor height, nor depth nor anything else in all creation, will be able to separate us from the love of God in Christ Jesus our Lord'. Next it will be demonstrated that the principle of reversal establishes those vindicated by faith as an alternative community of believers.

\subsection{The formation of an alternative community of believers}

Barton $(1982 ; 17)$ argues convincingly that the cross served as a potent symbol for community formation. The communal identity in the Pauline communities stood diametrically opposed to traditional Jewish conventions. The cross constituted the dividing

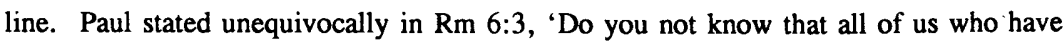
been baptized into Christ Jesus were baptized into his death?' The 'outsiders', as Barton designates them, are those who reject the crucified Christ: 'a stumbling block to the Jews and folly to Gentiles' (1 Cor 1:23). The cross provided the basis for an 
individual and community identity which was quite different from contemporary social classifications. Barton provides the following examples: The believers regarded themselves as being 'all one in Christ' (Gal 3:28), as 'sons of God' (Gal 3:26-4:7; Rm 8:14-17), as 'new creation' (2 Cor 5:17) and as the 'body of Christ' ( $R m$ 12:4-8). In $\mathrm{Rm}$ 10:9-11 Paul reiterates clearly that faith which identifies one with the community is resurrection faith. Resurrection faith features such a characteristic of finality which distinguishes the Christian community from outsiders.

The existence of the community is, by virtue of a divine initiative, founded upon identification with the risen Christ ${ }^{20}$. According to $\mathrm{Rm} 4: 16 \mathrm{ff}$ it is God who established a community of faithful in the Old Testament by transforming the impotent and infertile bodies of both Abraham and Sarah. The promise was that this community of faithful, consisting of Gentiles as well as Jews, would ultimately find fulfillment. It is this very God who, according to $\mathrm{Rm}$ 4:16ff, calls into being an alternative universal community of believers. This community, Barton (1984:70) claims, is one whose 'self-under-standing is mirrored in, and enlarged by its representations of the crucified and risen Christ'. That such representations brought psychological relief and sociological reinforcement to the persecuted minority societies of Christians is clear from $\mathrm{Rm}$ 8:31ff. Phil 3:3-11 shows, as argued by Barton (1984:70), a displacement of the symbolic world of Judaism by the symbolic world of the resurrection. Belief in Jesus' resurrection appears as Barton (1984:69) continues to show, to have contributed significantly to sanctioning the building of 'another world to live in'. This world constitutes itself as an alternative community of believers.

\subsection{The theodicy of the death and resurrection}

The resurrection of Jesus, as indicated above, was a constitutive principle in the social and cultural formation of the Roman Christian community. This belief in the resurrected Lord was strong enough to establish a distinct social and cultural order. Neyrey (1986:93), the social anthropologist, argues that belief in the resurrection constituted the core of a purity system which organized the Christian community as a distinct socio-cultural group. Neyrey traces the principles of this purity system back to Christ, the 'limit breaker', who sets up new criteria for purity maps of people, places, time and destiny. The resurrection served as a powerful theodicy, justifying the continuity of the community after the death of Jesus. Barton (1984:70) assumes that the death of Jesus and other community members posed a threat to the life of the early Christian society (1 Cor 15:14 and 17). This community needed the assurance of the presence of its founder in order to continue. Barton (1984:70) indicates that belief in the resurrec- 
tion guaranteed the presence of Jesus (Mt 28:2) universally. Barton argues from his sociological viewpoint that the transformation of Jesus, represented by the resurrection, was at the same time the transformation of the community.

Barton (1984:72-73) argues that the binary opposition of death and resurrection in Pauline discourses established the parameters for the formation of Christianity in a new religious order. This binary opposition of death and resurrection also manifests in Romans 5:10. Romans 5:10 juxtaposes reconciliation through the death of Christ to salvation through the life of Christ. Adherents to the faith were transformed and established in fellowships such as the communities of Rome, Galatia or Corinth. The euphoria of the resurrection became the driving force in Paul's mission to the gentile world.

\subsection{Resume and critique}

The social theory of the New Testament interpretation contributes a fresh perspective of Christian origins, the early Christian community and the social interaction between this community and the macro-social systems. The socio-critical consciousness further provides a corrective on the logical positivistic methods of historical critical inquiry into the meaning of the text.

Within this framework, the above sociological analysis attempts to show that the cross and resurrection of Jesus, as indicated by Barton (1984:67), provide an 'alternative agenda for the formation of individual and communal identity' which eventually led to the establishment of separate Pauline communities. Most contributions to a socio-semiotic analysis regard the cross and resurrection in the letters of Paul as belonging to the core of the Gospel of St.Paul. Barton, among other exponents, believes the evidence they produce is adequate to prove that the communal identity was strong and coherent enough for the formation of the early Christian community. The following critical observations in the social interpretation of $\mathrm{Rm}$ 8:31-39 seem necessary.

* Both Dunn (1990:262) and Craffert (1993:241) question the 'undifferentiated and all-inclusive' sense in which Watson and others deal with the phenomenon of firstcentury Judaism. References to a 'messianic Israel' by Meeks (1982:274), or 'the traditional Jewish faith' by Räisänen (1985:546), or 'the Jewish community' by Watson (1986:19), designate first century Jewish communities in a piecemeal fashion. Qumran, Philo, Joseph and the Gospels project images of Jewish communities, before $70 \mathrm{CE}$, consisting of many parties and many modalities. Acts and the 
Pauline epistles will suffice to show that the same argument holds true for the early Christian communities. Craffert (1993:237) indicates that ideological components and sociological components of arguments are often isolated in a way that leads to confusion or a mixing of categories. Theological arguments, and often ideological arguments, are used to substantiate sociological conclusions and vice versa.

* The use of sociological theories by Theissen, Meeks and Watson are also not beyond criticism. Elliott (1986:11) indicates that the selection and classification of data with regards to 'roles', 'factors' and 'functions' signify an organized theoretical framework never comprehensively explained. Various sociological theories are merged into functionalistic methods. Yet the major concern of scholars like Craffert (1993:240) lies in the fact that first century Judaism is conceived of as a disembodied 'normative Jewish community'. Both Meeks (1982:267) and Watson (1985:38-41) present the origins of Christianity as a process of transformation from a first-century Jesus movement to a sect which Paul separated from Judaism. It goes without saying that this interpretation results in a one-dimensional viewpoint. First century Judaism, however, was not a unified movement which constituted itself in any normative Judaism. Evidence provided by Nickelsburg (1985) and Craffert (1993:246) suggests that first-century Judaism was a heterogeneous 'complex and variegated phenomenon'. There was no normative Judaism from which Paul separated Christian communities. The designation of a 'sect' does not do justice to the household communities which spontaneously arose. Craffert (1993:258) concludes that Paul was probably, in what he did and what he said, as mainstream as any other Jewish divine $\operatorname{man}^{21}$ of his time.

* The discussion of the social significance of the cross and the resurrection derives the distinctive character of Christianity from the ministry of Jesus and the early Church. This fact is overlooked by Watson and others who locate the initiative for the establishment of Christian communities, and finally the church, in Paul's mission to the Gentiles. Paul was not the founder of the early Christian church. Paul established the Gentile mission churches. The 'radicalism', the 'charismatic creativity', the infringement of the purity maps of persons and the purity maps of places derive from the earliest Jesus-movement and the ministry of Jesus. Holmberg (1990:104) emphatically states that Jesus could not be contained in Judaism. The ministry of Jesus exceeded the purity systems of Judaism.

The sociological analysis above, nevertheless, provides the exegete with much 'new information'. Results of the sociological analysis can be combined with the results of a structural exegesis. The new perspectives of the sociological analysis which combine 
with the results of a structural exegesis become 'old information' in the process of merging. The results of structural exegesis and socio-semiotic analysis now find their way into the encyclopaedical knowledge of the reader.

\section{AN INFERENTIAL SEMIOTIC ANALYSIS OF 8:31-39}

Sperber and Wilson (1986:7-15) provide an extensive critique of semiotic decoding. The inferential devices of Relevance Theary are nevertheless not incompatible with semiotics. Relevance Theory supplements semiotics. Sperber and Wilson (1986:14) state: 'an inferential process can be used as part of a decoding process ... (p15) Thus different experiences with inferential processes may nevertheless converge on the same logical system'. I have chosen 'inferential semiotics' as a designation for the level at which Relevance Theory converges with semiotics in the decoding process. An 'inferential semiotic analysis' will subsequently apply the pragmatics of Relevance Theory to the interpretation of $\mathrm{Rm} 8: 31-39$.

\subsection{Introduction: Romans 8:28-30}

In $\mathrm{Rm}$ 8:29 the expression 'image of his Son' is used with an 'ostensive inferential' communicative intention. The principle semantic subject was clearly established by the

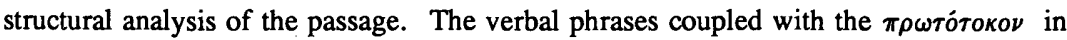
verse 29 particularize the suffering righteous servant as the principle subject.

The 'image of his Son' focalizes on 'elements of suffering. Verse 35 reinforces the elements of suffering: tribulation, distress, persecution, famine, nakedness, peril or the sword. The vocabulary of verse 35 describes conditions among others reminiscent of the Deuteronomistic imagery of the exodus into the wilderness and the conquest.

The 'image of his Son' stands in a relation of identification with the 'suffering righteous servant' as principle subject. The faithful are predestined to conform with all characteristics of the suffering righteous servant. This notion applies to those who unconditionally love God. It also applies to those who are called by God to fulfill his purpose. God predestined those to conform to the 'image of his Son'. The image of his Son is the image of the suffering servant. Faithfulness to the divine call means conforming to suffering righteousness. These characteristics are compatible with semantic features discussed in section 4.2.2 above: (humiliation) (obedience) (fidelity) (elect) (ministry) (suffering) (vicarious) (atonement).

Verse 28 contextualises the notion of suffering with new information. A reversal of suffering begins. The processing of old information with new information gives rise to a multiplication effect. Sperber and Wilson (1986:48) comment as follows on the 
multiplication effect: 'The greater the multiplication effect the greater the relevance'. The new information of verse 28 is contained in the expression 'all things work together for the good'. The servant corporately represents the faithful. It is this corpo-

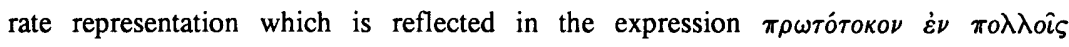
$\dot{\alpha} \delta \varepsilon \lambda \phi o i \varsigma$ in $\mathrm{Rm}$ 8:29. Verse 30 articulates the contextual effects of the unconditional fidelity. God justifies the servant. Verse 30 further explicates the contextual implications of the justification of the servant in the glorification and exaltation which follows.

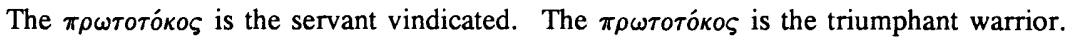
The contextual effects and implications of righteousness may be articulated in such features as compiled in section 4.2.2: (justification) (vindication) (deliverance) (confirmation) (glorification) (exaltation) and (thanksgiving).

\subsection{The relevance of Romans 8:31-39}

Rm 8:31 opens with a rhetorical question which alludes to the suffering righteous servant in Ps 118:6. This is a hymn of thanksgiving at the Feast of Tabernacles (Ps 118:27) when the king enters the temple courts. God vindicated and delivered the king. The righteous ones (verse 20 uses righteous in the plural) are embodied by the king. His righteousness has been sustained and the people share his glory. The servant

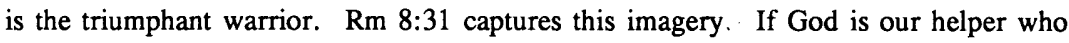
can rise against us? $\mathrm{Rm}$ 8:31 grounds this deliverance in God's unconditional love towards humanity. He who did not withhold his own Son, but gave him up for all of us, will he not with him also give us everything else? The unconditional sacrifice of his own Son is stated in the language of Gen 22:16 which narrates the sacrifice of Isaac by Abraham. This reference is a vehicle of the divine purpose of restoration and redemption. The unconditional fidelity of the righteous servant results in glory and exaltation.

$\mathrm{Rm}$ 8:31 alludes to the tradition of the suffering righteous one in the Old Testament. The reference is more particularly to Ps $118: 6$, 'with the Lord on my side I do not fear'. In Rm 8:31-39 Paul focalises the imagery of the suffering righteous one differently from previous contexts. He reinterprets the servant in victorious language of the conquest. In Rm 8:31-39, as indicated in note 7 above, one encounters a shift in perspective. The perspective shifts from focalizing on features of suffering to focalising on features of triumph, vindication and thanksgiving. God is an invincible eschatological warrior. God guarantees the victory.

Romans 8:31-39 achieves relevance in a variety of ways which manifest the intentions of the Pauline discourse. The relevance may be inferred from the discourse which juxtaposes the suffering servant and the suffering righteous one in a synonymous 
parallelism. The first parallelism, pertaining to the suffering servant verses 32-34, exalts Jesus as the eschatological judge of humanity. The second parallelism, pertaining to the suffering righteous one verses $35-38$, exalts the faithful to a victorious life. The relevance of the discourse is achieved by fulfilling the author's communicative intentions. Fulfilling the author's communicative intentions means changing the mutual cognitive environment of the sender and the recipients. Changing the cognitive environment will later be explicated in contextual effects and contextual implications under the following headings:

\title{
7.2.1 Parallel contexts and contextual effects
}

The double symmetrical parallelism in $\mathrm{Rm}$ 8:31-39 merges two entities with distinctive characteristics: Sentences 301-306 characterise the suffering servant primarily; sentences $307-310$ characterise the faithful community as suffering righteous ones. The incompatible becomes comparable in discourse. Suffering righteousness is the common denominator. In Section 71 the mutual cognitive environment of suffering righteousness became apparent. The double parallelism makes the suffering of 'the servant', in S 301-306, and the faithful community as 'righteous ones', S.307-310, mutually manifest.' It is not only the contexts which are comparable; the contextual effects and implications are also comparable. The contextual effects and implications now to be considered will show how parallelism 'arises in pursuit of relevance'. Sperber and Wilson (1986:222) continue:

\begin{abstract}
A speaker aiming at optimal relevance would deliberately introduce such linguistic parallelism only if s/he expected them to lead to a reduction in the hearer's processing effort, and in particular, if $s /$ he thought that the search for parallel contexts and contextual effects would be rewarded (the spelling of $s /$ he is my own to make the quote gender-sensitive for Paul's context).
\end{abstract}

Suffering righteousness provides the parallel with a context. Features such as discussed in section 4.2.2. (vindication) (exaltation) (victory) (deliverance) (glory) (liberation) (uniqueness) (triumph) (universal) (justification) (judgement) (righteousness) are stored in the encyclopaedic memory of the ideal reader. Such features drawn from the reader's encyclopaedic knowledge of the counter-determining context are made available to the interpretation of the symbolism. The syntactic equivalence in the comparison of the servant, S 300-306, and the righteous ones, S 307-310, provides a 
framework for comparison of semantically equivalent characteristics of both figures. The double parallelism 'reduces' the topic from the subject of the 'suffering righteous servant' to the 'suffering righteous community' of Rome. The underlying premise of the suffering servant is made mutually manifest in the following way:

Sentences 301-306 relate to a 'state of affairs' descriptive of Jesus as suffering righteous servant. This becomes evident from high frequency utilisation of the $\dot{v} \pi \grave{\varepsilon} \rho$

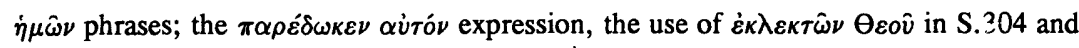

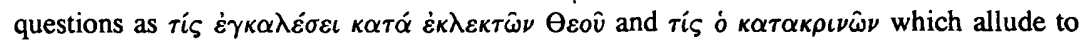
Is $50: 8$ and 9 . The juxtaposition of death/resurrection and suffering/vindication provide contextual effects strengthening the imagery.

The parallelism of the suffering servant in sentences 302-306 displays a chiastic order. The chiasm may be represented as follows:

* Sentence 302.1 carries the theme of suffering and deliverance. The discourse makes the sacrifice of Jesus mutually manifest: 'He who did not spare his own Son but gave him up for us all'. The verb é $\phi \varepsilon i \sigma \alpha \tau o$ coupled with $\pi \alpha \rho \varepsilon \dot{\delta} \omega \kappa \varepsilon \nu$ provides language reminiscent of Abraham's willingness to obey the call to sacrifice Isaac and the deliverance provided by God in Gen 22:16. The $\dot{\alpha} \lambda \lambda \dot{\alpha}$ in 302.2 is a contrastive conjunction. The expression 'but he gave him up for us all' alludes to the previous context $\mathrm{Rm} 4: 25$, which in turn refers to Is $53: 12$ as indicated in notes 10,11 and 12 of section 4.2. The utterances in 302.1 and .2 are 'ostensive'. These intertextual references carry the theme of substitution as synthetic implication into the context of sentence 302 . The contextual effect of $\sin$ bearing is that it makes provision for justification. Sentence 302 provides a 'stimulus' intended to change the cognitive environment of the reader: 'How will he not also give us all things with him'? This is a question which offers an answer. The question appropriates Deuteronomistic language of conquest (compare Deut 4:22 in note 15), used to reinterpret the servant in Is 53:12. The expression has illocutionary force. The question reinforces the unconditional love manifest in the sacrifice which Jesus makes on the cross in $\mathrm{Rm}$ 5:6-8. God will accomplish His purpose. God declares the faithful righteous. The subject of suffering in sentence 302 is about to be contrasted with the subject of vindication in sentence 305.

* Sentence 303 poses the rhetorical question: 'Who shall bring any charge against God's elect ones?' The rhetoric facilitates a shift in the discourse from the subject of his own Son, the servant (S 302.1), to the contextual effect of his sacrificial 
death. The contextual implication of the sacrificial death is that the servant secures

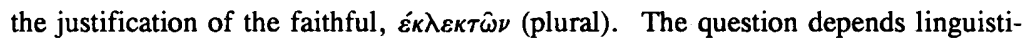
cally on the forensic context of Is 50:8: 'Who will contend with me? ... Who is my adversary?' The contextual implication makes it mutually manifest that the faithful are indemnified. The symbolism juxtaposes the features (condemnation) /(vindication). The context provides (vindication) with forensic meaning.

* Sentence 304: 'God it is who justifies' converges on the intersection of both questions in sentence 303: 'Who shall bring any charge against God's elect?' and sentence 305: 'Who is to condemn?' Sentence 304 is the focal sentence. Divine justification renders the servant righteous, as contextual effect. The perlocutionary force of the question makes mutually manifest that it is God who negotiates all adversity directed against the servant. The language remains linguistically dependent on Is 50:8.

* Sentence 305: 'Who is to condemn?' reinforces sentence 303: 'Who shall bring any charge against God's elect?' Sentence 305: 'Who is to condemn?,' in its entirety, articulates the contextual effect of sentence 304: 'God it is who justifies'. The question implies the incontestability of God's judgement. The underlying assumption characterizes divine judgment with the attribute of finality. Divine judgment is final judgment. The contextual implication is clear. There is no other authority beyond divine authority.

* The focaliser in sentence 306 directs the discourse to the subject of vindication. Jesus is eschatological advocate: 'Is it Jesus, who died, yes who was raised from the dead?'. The elaboration 'who is at the right hand of the father' is an 'ostensive inferential communicative' phrase. The purpose of the expression is to 'enlarge' the readers' cognitive environment. This ostensive phrase portrays Jesus as the enthroned eschatological king. Paul appropriates the language of Ps 110:1 to reinterpret the victory of the risen Lord as eschatological warrior. $\mathrm{He}$ is significantly 'seated' in a privileged position. He is the royal servant seated at the 'right hand side' (Ps 80:18). The conquest is complete. The victory won.

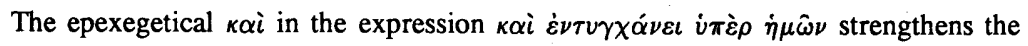
'ostensive' character of the utterance by 'showing' us more about Jesus. Jesus is our advocate, he intercedes for us. He is, as indicated in note 7 above, the victorious servant. The victorious servant is the one who loves us. The servant will come as eschatological mediator of humankind. To him belongs all the characterristics of the eschatological warrior king. It is by virtue of his righteousness that 
he holds the authority of the eschatological judge of humanity. Relevance is achieved by changing the reader's cognitive environment. In their suffering they know that Jesus, who was tortured, is waiting at the destiny of the world. By changing the readers' cognitive representation of the world the discourse achieves relevance.

\subsubsection{The change in mutual cognitive environment}

In the parallel of sentences $307-310$ the focaliser shifts attention from the context of suffering to that of vindication. The chiastic arrangement in the parallelism correlates sentences 307 and sentence 310 . The relation between sentence 307 and sentence 310 is determined by a relationship between the theme of 'question' and the theme of 'reply'. The question in sentence 307, 'Who will separate us from the love of God?,' reveals the intentions of the author. Sentence 310 answers the question: 'For I am sure that neither death nor life ..., will separate us from the love of God in Christ Jesus our Lord'. The parallel contains a causal relationship between these sentences which becomes evident in relationship of 'intention' and 'fulfillment'. The recognition of the fulfillment of the author's intentions changes the cognitive environment of the readers. It is the recognition of the fulfillment of these intentions which achieves relevance. Let us determine the relevance of the outer ring of the parallelism.

* Sentence 307 enumerates conditions which threaten to separate us from the love of Christ. Paul mentions his experience of these conditions in 1 Cor 4:11 and 12, 2 Cor 4:9, 11:26 and 27 and Gal 5:11. The conditions are also evident from previous contexts in $\mathrm{Rm} \mathrm{2:9}$ and 5:3. Paul evidently knows that the Christian community of Rome, as outlined in section 6 above, survived conditions of 'suffering, distress, persecution, famine, nakedness and perils'. Their conditions are reinterpreted by servant imagery of the exodus and conquest. Such conditions were familiar to Paul. It is the function of Sentence 307 to make the context, entailed by such conditions, mutually manifest. The rhetorical question: 'Who will separate us from the love of Christ?' relies on two premises. The first premise is that the power of the resurrection vindicates Jesus and exalts him to the position of the eschatological judge of humanity (S.306). The second premise is that God who delivered his Son for us will grant us all things with him (S.302.1/2). The assumption which emanates from these premises is that the grace of God sets limits to all hostile conditions which may inhibit the faithful to execute their calling. Nothing will separate the faithful from the love which unites them to Christ. Grace changes the community's representation of the world and achieves relevance thereby. 
* The parallel sentence 310 enumerates agents who threaten to separate us from the love of God. The agents of S 310 substitute the conditions of S.307. Paul shares mutual knowledge of these agents which attempt to separate us from the love of God: life and death (1 Cor 3:22), angels and principalities (1 Cor 15:24, Eph $1: 21,3: 10,6: 10$ and $\mathrm{Col} 1 ; 16,2: 10$ and 15.), things present and things to come (1 Cor 3:22), powers (1 Cor 15:24), height and depth (perhaps Eph:12) and 'anything else in all creation'. Paul also knows that the Christian community of Rome suffered such evil conditions which the authorities inflicted upon them. The discourse makes both the community's knowledge of suffering and Paul's knowledge of suffering mutually manifest. Many of the community who returned home to Rome, after 54 CE suffered 'high status inconsistency'. Yet the power of the resurrection accomplished a 'reversal' of their status. Their faith in the resurrected Lord gave them a distinct identity. Community formation inevitably resulted as contextual effect. The expression $\dot{\varepsilon} \nu$ X $\rho \iota \sigma \tau \hat{\varphi}$ 'I $\eta \sigma o \hat{v} \tau \hat{\varphi} \boldsymbol{\varphi} \kappa \nu \rho i \varphi \varphi \dot{\eta} \mu \hat{\omega} \nu$ contains two premises. The first acknowledges Jesus as benefactor of the love who unites believers with God. The second premise contained in the expression $\tau \hat{\varphi} \kappa v \rho i \varphi \dot{\eta} \mu \hat{\omega} \nu$ acknowledges community formation as a result of the identification with Jesus who facilitates the love of God. The love of God changed their representation of the world as a place hostile towards them. The discourse achieves its relevance by a change of the cognitive environment of the community. Let us next consider the inner ring of the parallelism.

* In sentence 308, see note 8 above, Paul alludes to Ps 43:23 (1xx) in contradistinction from Is 53:7. Paul does, however, reserve Is 53 for the servant in Phil 2:7. Ps 43:23(LXX) strengthens the theme of the suffering of the righteous one. The imagery alludes to sheep brought to the altar as sacrificial offering. Cranfield (75:440) observes that Rabbis applied this verse to the death of martyrs (e g 2 Macc 7) and also to the life of the godly who dedicate themselves wholeheartedly to the service of God. In the symmetry of the parallelism the theme of the suffering righteous contrasts the theme of vindication in sentence 309.

* In sentence 309 the discourse achieves relevance by changing the cognitive environment of the readers. The suffering ones in the persecuted community become victorious. They are more than conquerors. The subject of the verb $i \pi \varepsilon \rho \nu \kappa \hat{\omega} \mu \varepsilon \nu$ refers to the faithful community. Sentence 309 identifies the faithful community with the victorious servant, as indicated in section 4.2.3 above. 
In Sentence 310 the love of God conquers all agencies of destruction. The grace of God sets limits to all forces of evil, even to the power of death itself. If even death changed, humankind cannot remain the same. Grace changes their cognitive environment of the world and achieves relevance thereby. The faithful of Rome were possibly never the same again.

Where $\sigma \tau \varepsilon \nu 0 \chi \omega \rho i \alpha$ reigns the faithful sets humankind free. Where $\delta \iota \omega \gamma \mu \grave{s}$, they bring peace. In $\lambda_{\iota} \mu \grave{s} \varsigma$ they provide food and relief. They offer clothing and care to $\check{\eta}$

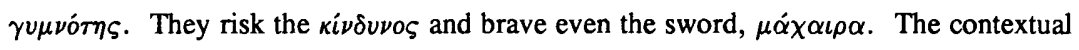
effect of the change of cognitive environment make the early Christian community a derived source of salvation, and a source of grace.

The 'endless semiosis' of Romans also achieves relevance in the South African society, a society emerging from oppression and exile. The Christian community in the South African society is in want of reinterpretation. It is a community in the throes of exodus and conquest. This Christian community is an alternative community. $\mathrm{Rm}$ 8:31-39 gives content and hope to such a community. This is the community in process of reconstruction and development. It is a suffering but victorious community. It yearns for a change in cognitive environment that mutually manifests the servantvictory. And, as such, it is a microcosm of the world beyond.

\subsection{Resume}

The structural analysis in section 5, the socio-semiotic reading in section 6 and the inferential ostensive reading in section 7 above provided three distinct interpretations of Rm 8:31-39.

Section 5.2 provided a structural description of the text with the vindication of Jesus as central theme. The antithesis in the parallelism contrasted the features of (suffering)/(vindication), (death/resurrection) and (condemnation)/(vindication) of the suffering servant. Christ as eschatological mediator indemnifies the servant. The imagery of the servant merges with the faithful community as 'righteous ones'. Righteousness is triumphant. With God as Judge, justice is accomplished.

The synthetical parallelism in section 5.2.2 focalises on the vindication of the righteous servant. The victory of the servant is appropriated for the community as suffering righteous one. No evil condition or agent of suffering can separate the servant from the love of Christ. The triumph of God's grace leads to the vindication of the faithful.

In section 6 the significance of $\mathrm{Rm} 8: 31-39$ and its structure is contextualised in a sociological analysis of the death/resurrection theology. Faith in the resurrection reverses conditions of suffering, humiliation and condemnation. The power of the 
resurrection vindicates, exalts and justifies the righteous ones. Victory empowers the weak and those of 'high status inconsistency'. It overturns the notions of honour and shame.

Section 6.2 acknowledges the formation of an alternative community of believers. Resurrection-faith provides a theodicy to the faithful community. Their lives remain subject to the perils of unrest, persecution and suffering. Jesus, who shared their suffering, is waiting at the destiny of the world. The epistle changed their cognitive representation of the world. $\mathrm{Rm}$ 8:31-39 makes the change of cognitive environment mutually manifest. The change of cognitive environment transforms the community. The community becomes a source that disseminates the love of God. They provide comfort for those suffering hardship, deliverance to those in distress, shelter to those persecuted, relief for those stricken with famine. They clothe the naked, risk perils and brave the sword.

Section 7 contextualises the vindication of the faithful community. Relevance is achieved by making the change of cognitive environment mutually manifest. Their faith become victorious. They are more than conquerors. The author's intentions are achieved and all expectations fulfilled.

Old information pertaining to the exodus/conquest and the servant merges with the new information. The warrior/servant becomes victorious in conquest. The early Christian community of Rome is reinterpreted as the vindicated servant. Faith is victorious where grace abounds.

\section{CONCLUSIONS}

The resume above reflected on the process of reading and rereading the epistle. Articulating the signs is the process of 'endless semiosis' (Peirce). Reinterpreting the signs is 'the law of significance' (Lacan). Interpretation and reinterpretation create a multiplication effect. The greater the multiplication effect the greater the relevance (Sperber and Wilson). The practice of interpretation in changing historical conditions produces the multiplication effect. The 'logical interpretant' (Peirce) which offers the finality of interpretation (Aristotle and Thomas Aquinas) will always elude us.

Human cognition remains historically contingent. Human cognition must content itself that, despite all endeavour to achieve finality, it can only produce truthperspectives on meaning. Human knowledge is perspectival. Human knowledge of meaning is incomplete. New Testament interpretation must be recognised as a multiple logos. This fact can best be explained by the following simile: As various layers of colour constitute a rainbow so will various layers of interpretation constitute the meaning of a text. The polymorphous character of meaning prevents the exegete from con- 
ducting interpretation in an act of hubris. The limitations of physical environment and changing historical conditions will always make interpretation relative. Critical responsibility will always conduct exegesis with self-restraint. Exegesis is a daunting task but let us nevertheless accept its challenges. It is reassuring to consider that although our knowledge of meaning is perspectival it nevertheless is truth-preserving.

Knowledge is truth-preserving when it is in logical form and able to be confirmed or disconfirmed. Truth-perspectives reinterpret our cognitive representation of the world. Changing the cognitive environment of the reader makes interpretation of the text relevant. Conditions, ever changing with times, challenge the exegete to interpret the text relative but relevant to the historical contingent situation. Interpretation generates reinterpretation. The legacy of an 'open text' makes New Testament interpretation an 'open science'. The 'writerly text' provides New Testament scholarship with a 'writerly discourse'. Relative though this endeavour may be, the fulfillment of communicative intentions changes the cognitive environment of readers. Though interpretation is perspectival and our endeavour relative, yet may we know that changing the cognitive environment of our readers achieves the relevance of our discourse.

\section{Endnotes}

1 Sperber and Wilson (1986:49) define ostension as follows:

We will call such behaviour - behaviour which makes manifest an intention to make someting manifest - ostensive behaviour or simply ostension ... (p 60/1). To communicate by ostension is to produce a certain stimulus with the aim of fulfilling an informative intention .... Communication alters the mutual cognitive environment of the audience and communicator. Mutual manifestness may be of little cognitive importance, but it is of crucial social importance .... (p 62). This shows how ostensive communicaticn may have social implications that other forms of information transmission dot no.

2 Sperber and Wilson (1986:109) define contextual effects as follows:

To modify and improve an context is to have some effect on that context - but not just any modification will do .... (p 115). Contextual effects are achieved only when, as in the case just described, the new assumptions displace an assumption already present in the context, with subsequent weakening or erasure of other contextual assumptions linked to it by relations of analytic or synthetic implication. 
3 Sperber and Wilson (1986:108) define contextual implications as follows:

A contextual implication is new information in the sense that it could not have been derived from $\{C\}$, (where $\mathrm{C}=$ context), the stock of existing assumptions, alone; however, it is not just new information, since it is neither an analytic nor a synthetic implication of $\{P\}$, (where $P=$ new information) the newly presented information, alone. It is a synthesis of old and new information, a result of interaction between the two.

4 Sperber and Wilson (1986:207) explicate contextualising with the following definition in which $\{P\}$ symbolises a set of assumptions that represent the world and $\{C\}$ the context:

'Let us call a deduction based on the union of $\{P\}$ and $\{C\}$ as premises a contextualisation of $\{\mathrm{P}\}$ in the context $\{\mathrm{C}\} \ldots . \mathrm{C}\}$ alone. These will call the contextual implications of $\{P\}$ in $\{C\}$. The contextualisation may also give rise to contextual effects .... The contextualising of old information into new information is relevant for the process which leads to the interpretant or the aesthetic object of the text.

5 Russian Formalism provides a classic example. Formalism regards poetic language usage as the defamiliarisation of language as opposed to the norm of standard language usage ( or automatisation as in everyday language usage). In Russian Fomalism this practice leads to a reduction of literariness to the application of the principle of ostranenie which designates the defamiliarisation of ordinary language usage. Likewise, the Prague structuralist Havranek (in Garvin 1964:18) called the highlighting of sentence constituents foregrounding (aktualisace). Both the Russian ostranenie and the Czech term aktualisace reduce poetic language usage to a consciousness of structural devices employed in the text.

Philophers such as Rauche (1985:4) continually warn against the tendency in the humanities to merge practice and theory in functionalistic methods of scientific enquiry. The reduction of society to a mere system of social interaction or to the totalitarian functionalism in Marxism will suffice as examples. In literary interpretation the reduction of interpretation to the application of analytical and structural methods, feminist analysis or a materialist interpretation will run the same risks.

6 The suffering righteous Son of man in the Similitudes of Enoch shares similar characteristics. Higgens (1980:8) rightly remarks: 'Thus the one like a Son of man becomes representative of the true Israel. In both cases he is a collective figure, without becoming directly a messiah of redeemer'. Compare Mowinckel (1956:361), Perrin (1966:24), Jeremias (1971:270), Cullmann (1971:155) and Casey (1979:25) with reference to 1 Enoch $39: 6 ; 48: 5 ; 55: 4 ; 61: 6 ; 62: 2 ; 69: 27$ 
and 4 Exra 13:3. Also features such as (praiseworthiness), (humanity) and (glory) are relevant for the imagery. The suffering righteous one stands in a tenor/vehicle relationship with true Israel or saints of the Most High as the proper term of reference. Very appropriately reference to Ps 118:6 in Rm 8:31 alludes to the song of victory of Israel. God exalted Israel in his steadfastness. Ps 118 is a song of victory and thanksgiving for the stone which the builders rejected and which has become the head of the corner (Ps 118:-22).

$7 \mathrm{Rm}$ 8:36 alludes to the suffering of the righteous in Ps 44:23: 'Because of you we are being killed all day long and counted as sheep for the slaughter'. Rm 8:31 vindicates the faithful with reference to Ps 118:6 'with the Lord on my side I do not fear'. Compare Mowinckel (1956:316), Casey (1979:25 and 106) and Dunn (1980:75) with reference to Dan 7:14 and 27; 1 Enoch 50; $52: 6-9 ; 55: 4 ; 56: 5-8 ; 57: 1-3$ and $61: 8$.

8 (Faithfulness) is chosen as correlative for (justification) to articulate characteristics of the servant such as (divine fidelity), (obedience), (humility) exercised in voluntary submission to execute the divine call. Compare the comments of Pesch (1975:22 and 189) on the trustworthiness of the sevant with reference to Mk 14:38 and Ps 51:14 and Mk 14:65 with reference to Ps 110:1; 5:11; 24:4-6 and 35:24. Also consult Gemser (1968:11.p 144, IV p 133) on the royal Son of man in Ps $80: 18$ and the victorious king in 110:1.

9 Kleinknecht (1981:148) regards Is 43:3ff as relevant: 'die Stellvertretung des Gottesknecths wird von Jes 43 her als kpr, das Gott aus freier Liebe gibt, verstanden'. Compare Is 43:3 and 53:4,5 and 12 with $\operatorname{Rm} 4: 25 ; 5: 1$ and 1 Cor 15:3.

10 Deist (1985:7) shows the appropriation of Dt 1:37; 3:23-27 and 4:21-22 in Is 53:4,5,6,8 and 12: 'he bore our sufferings; he was tortured for our iniquities; upon him was the quilt of us all; he was cut off from the world of living men; $\ldots$ he bore the sins of many'. Romans 4:24-25; 5:1-2; 5:15 and 19 depend linquistically on these sayings.

11 Deist (1985:7) indicates how Ex 32:31; Num 11:2; 14:11-19; 16:22; Deut 9:18 and 20 are appropriated in Is 53:12, 'he interceded for their transgressions'. $R m$ 4:24 depends linguistically on Is 53:1.

12 Watts (1988:117-119) and Beuken $(1979,11 \mathrm{~A}: 130)$ show that the verb 'elect' equally applies to Israel (Is 43:20 and 45:4), Cyrus (Is 42:1) and Darius (Is 49:7). The verb is also used of believers in Is 58:5-6, 65:9,15,22 and 66:4.

13 Both Beuken (1979: 11 A:297) and Watts (1988:134) regard (legitimacy) as a vital feature for the servant (Is 42:18-19). 
14 Deist (1985:7) indicates how Dt 4:22 is appropriated in Is 50:8 and 53:11-12. Rm 8:33 depends linguistically on Is 50:8.

15 Watts (1988:197) includes (salvation) here and refers especially to Is 51:4-6.

16 Compare Beuken $(1979,11 \mathrm{~A}: 131)$ with reference to Is $42: 5-9$.

17 Compare Beuken $(1979,11 \mathrm{~A}: 279)$ with reference to Is $48: 18-19$.

18 Schöllgen (1988:73) douts whether Meeks adequately demonstrates the presence of 'status inconsistency' in the early communities. Elliott (1985:331) believes 'status inconsistency' can also apply to persons of downward mobility. To how many Christians in these congregations would Meek's hypothesis apply? Rohrbaugh (1984:543) detects traces of a 'sociocentrism' evident in the tendency to see things the other side of the Industrial Revolution as if the revolution changed nothing in our patterns of perception.

19 Passages such as 1 Cor $15: 4$, 'Christ was raised of the third day', circumlocute the divine initiative taken in the resurrection of Jesus by 'divine passive'. The divine passive also becomes evident in expressions like 'Christ ... was raised on the third day'. The passive transformation applied in derivation of this surface structure deletes "God" as agent of the action. The noun God is, nevertheless, recoverable from the context. This is also the case in 1 Cor 15:15. The linguistic rules governing recoverability may be found in Bach (1974:100).

20 A Jewish divine man, defined in terms of Craffert (1993:-259), is a teacher among first-century socio-religious groups who claimed 'ultimate truth for his viewpoints'.

\section{Works consulted}

Alexander, L 1986. Luke's preface in context of Greek preface writing. Novum Testamentum 18, 48-74.

Bach, E 1974. Syntactic theory. New York: Holt Rinehart and Winston.

Barthes, R 1974. S/Z, translated by R Miller. New York: Hill \& Wang.

- 1977. Elements of semiology, translated from the French by A Lavers \& C Smith. New York: Hill \& Wang.

Barton, S 1982. Paul and the cross: A sociological approach. Theology LXXXV, January, 13-19.

1984. Paul and the resurrection: A sociological approach. Religion 14, 67-75.

Best, T F 1984. The sociological study of the New Testament: Promise and peril of a new discipline. Scottish Journal of Theology 36, 181-194. 
Beuken, W A M 1979. Jesaja, Deel 11A. Nijkerk: Uitgewery G F Callenbach NV. (De Prediking van het Oude Testament.)

— 1983. Jesaja, Deel 11B. Nijkerk: Uitgewerij G F Callenbach NV. (De Prediking Van Het Oude Testament.)

Bremond, C 1964. Le message narratif. Communications 4, 4-34. 1966. La logique des possibles narratifs. Communications 8, 60-76.

Brooke-Rose, C 1958. A grammar of metaphor. London: Secker and Warburg.

Casey, M 1979. Son of man: The interpretation and influence of Daniel 7. London: SPCK.

Cole, P \& Morgan, J 1975. Syntax and semantics, 3: Speech acts. New York: Academic Press.

Cranfield, C E B 1975. A critical and exegetical commentary on the epistle to the Romans, Volume 1. Edinburgh: T \& T Clark. (The International Critical Commentary.)

Craffert, P F 1993. The Pauline movement and first-century Judiasm: A framework for transforming the issues. Neotestamentica 27/2, 233-262.

Culler, J 1981. The pursuit of signs: Semiotics, literature, deconstruction. London: Routledge and Kegan Paul.

Cullmann, O 1971. The christology of the New Testament. 3rd imp. London: SCM.

Deist, F E 1985. Reflections on reinterpretation in and of Isaiah 53. Old Testament Essays 3/3, 1-11.

De Liagre Böhl, F M Th \& Gemser, B 1968. De Psalmen: Text en uitleg. Nijkerk: Uitgeverij G F Callenbach NV.

Dunn, J D G 1980. Christology in the making. London: SCM.

- 1983. The new perspective on Paul. Bulletin of the John Rylands Library 65/2, 95-122.

1988. Romans 1-8. Dallas: Word Books (Word Biblical Commentary 38 A.)

1990. Jesus, Paul and the law: Studies in Mark and Galatians. London: SPCK.

1991. The partings of the ways: Between Christianity and Judaism and their significance for the character of Christianity. London: SCM.

Eco, U 1976. A theory of semiotics. Bloomington: Indiana University Press.

Eco, U 1979. The role of the reader: Explorations in the semiotics of texts. London: Hutchinson.

- 1984. Semiotics and the philosophy of language. London: The Macmillan Press.

Elliott, J H 1984. Social-scientific criticism of the New Testament: More on methods and models. Semeia 35, 1-33. 
Elliott, J H 1985. Review of the first urban Christians by Meeks, Wayne A. Religious Studies Review 11, 329-335.

Eichenbaum, B 1965. The theory of the 'formal method' in Lemon, L T \& Reis, M J 1965:99-139.

Erlich, V 1965. Russian formalism: History-doctrine. The Hague: Mouton.

Festinger, L 1964. When prophecy fails: A social and psyshological study of a modern group that predicted the destruction of the world. New York: Harper and Row. (Harper Torchbooks.)

Gäger, J G 1982. Shall we marry our enemies? Sociology and the New Testament. Interpretation 37, 256-265.

Gallagher, E V 1984. The social world of Saint Paul. Religion 14, 91-99.

Garvin, P L 1964. A Prague school reader on esthetics, literary structure and style. Washington: Georgetown University Press.

Genette, G 1980. Narrative discourse, translated by J E Lewin. Oxford: Basil Blackwell.

Goppelt, L 1975. Theologie des Neuen Testaments, 1 Teil. Göttingen: Vandenhoeck.

Gottwald, N K 1979. The tribes of Yaweh: A sociology of the religion of liberated Israel, 1250-1050 B.C.E. New York: Orbis.

Greimas, A J 1966. Semantique structurale. Paris: Larousse.

Grice, H P 1975. Logic and conversation, in Cole 1975:41-58.

1978. Further notes on logic and conversation, in Cole 1978:113-28.

Guiraud, P 1975. Semiology, translated by G Gross. London: Routledge and Kegan Paul.

Hartshorne, C \& Weiss, P (eds) 1974. Collected papers of Charles Sanders Peirce, Volumes 1 and 2. Cambridge, Massachusetts: The Belknap Press of Harvard University Press.

Havránek, B 1964. The functional differentiation of the standard language in Garvin 1964:3-16.

Hawkes, T 1977. Structuralism and semiotics. London: Methuen.

Holmberg, B 1978. Paul and power: The structure of authority in the primitive church as reflected in the Pauline epistles. Philadelphia: Fortress.

Holmberg, B 1990. Sociology and the New Testament: An appraisal. Minneapolis: Fortress Press.

Hock, R F 1980. The social context of Paul's ministry: Tentmaking and apostleship. Philadelphia: Fortress Press.

Holub, R C 1984. Reception theory: A critical introduction. London: Methuen. 
Ihwe, J (Hrsg) 1971. Literaturwissenschaft und Linguistik, 1 und 11. Frankfurt am Main: Athenäum.

Iser, W 1971. The implied reader: Patterns of communication in prose fiction from Bunyan to Beckett. London: Johns Hopkins University Press.

- 1976. The act of reading: $A$ theory of aesthetic response. London: Routledge and Kegan Paul.

Jackendoff; R S 1972. Semantic interpretation in generative grammar. Cambridge, Massachusetts: The MIT Press.

Jakobson, R 1960. Closing statement: Linguistics and poetics, in Sebeok 1960:350377.

- 1966. Grammatical parallelism and its Russian facet. Language 42, 399-429.

Jauss, H R 1977. Geschiedenis en kunst, in Bronswaer 1977:266-283.

1982. Toward an aesthetic of reception. New York: The Harvester Press.

Jeremias, J 1971. New Testament theology. New York: Charles Scribner's Sons.

Judge, E A 1980. The social identity of the first Christians: A question of method in religious history. Journal of Religious History 11, 201-217.

Käsemann, E 1974. Handbuch zum Neuen Testament: 8a an die Römer. 3.Aufl. Tübingen: J C B Mohr (Paul Siebeck).

Katz, J J \& Fodor, J A 1963. The structure of a semantic theory. Language, 170-120. Katz, J J 1972. Semantic theory. New York: Harper and Row.

Kleinknecht, K T 1981. Der leidende Gerechtfertige: Untersuchungen zur Altestamentlich-Jüdischen Tradition von 'leidende Gerechten' und ihrer Rezeption bei Paulus. Tübingen: Eberhard-Karls-Universität.

Kristeva, J 1980. Desire in language: A semiotic approach to literature and art. New York: Columbia University Press.

Leech, G N 1966. Linguistics and the figures of rhetoric, in Fowler R (ed), Essays on Style and Language, 135-156. London: Routledge and Kegan Paul.

Lemon, L T \& Reis, M J (eds) 1965. Russian formalist criticism. Lincoln: University of Nebraska Press.

Lenski, G E 1954. Status christallization: A non-vertical dimension of social status, American Sociological Review 19, 5-13.

Levin, S R 1969. Linguistic structures in poetry. The Hague: Mouton.

Maartens, P J 1980. Mark 2:18-22: An exercise in theoretically-founded exegesis, Scriptura: Journal of Biblical Studies 2, 1-54.

- 1986. The Son of man as a composite metaphor in Mk 14:62, in Petzer, J H \& Hartin, P J 1986:76-98. 
Malherbe, A J 1983. Social aspects of early Christianity. 2nd ed. Philidelphia: Fortress Press.

Malina B J 1981. The New Testament world: Insights from cultural anthropology. Atlanta: John Knox Press.

1983. Why interpret the Bible with the social sciences? American Baptist Quarterly 2/2, 119-133.

1984. Jesus as charismatic leader? Biblical Theology Bulletin 14, 55-62.

Meeks, W A 1982. The social context of Pauline theology. Interpretation 36, 266277.

Meeks, W A 1983. The first urban christians: The social world of the apostle Paul. New Haven Yale University Press.

- 1985. Breaking away: Three New Testament pictures of Christianity's separation from the Jewish communities, in Neusner \& Frerichs 1985:93-115.

1986. The moral world of the first Christians. London: SPCK.

Meyer, B F 1986. The early Christians: Their world mission and self-discovery. Wilmington: Michael Glazier.

Meyers, E M \& Strange, J F 1981. Archaeology, the rabbis, and early Christianity: The social and historical setting of Palestinian Judaism and Christianity. Nashville: Abingdon.

Mowinckel, S 1956. He that cometh, translated by G W Anderson. Nashville: Abingdon Press.

Mukařovský, J 1978. Structure, sign and function, translated by J Burbank \& P Steiner. London: Yale University Press.

1964. Standard language and poetic language, in Garvin 1964:17-30.

Neyrey, J H 1986. The idea of purity in Mark's Gospel. Semeia 35, 91-128.

1990. Paul in other words: A cultural reading of his letters. Louisville: John Knox Press.

Neusner J \& Frerichs E S (eds) 1985. To see ourselves as others see us: Christians, Jews, 'others' in late antiquity. Chico: Scholars Press.

Nickelsburg, G W E 1985. Revealed wisdom as a criterion for inclusion and exclusion: From Jewish secretarianism to early Christianity, in Neusner \& Frerichs 1985:73-91.

Nickelsburg, G W E 1993. Jews and Christians in the first century: The struggle over identity. Neotestamentica 27/2, 365-390.

Peirce, C S 1974. Elements of Logic, in Hartshorne \& Weiss 1974: Volume 2.

Perrin, N 1966. The Son of man in ancient Judiasm and primitive Christianity: A suggestion. Biblical Research 11, 17-28. 
Perrin, N 1968. The creative use of the Son of man traditions by Mark. Union Seminary Quarterly Review 23, 357-365.

Petersen, N R 1984. The reader in the Gospel. Neotestamentica 18, 38-51.

Petzer, J H \& Hartin, P J (eds) 1985. A South African perspective on the New Testament by South African New Testament scholars presented to Bruce Manning Metzger during his visit to South Africa in 1985. Leiden: E J Brill.

Raabe, P R 1984. The effect of repetition in the suffering servant song. Journal of Biblical Literature 103/1, 77-84.

Räisänen, H 1985. Galatians 2:16 and Paul's break with Judaism. New Testament Studies 31, 543-553.

Rauche, G A 1983. The function of method in the constitution of knowledge. Journal University of Durban-Westville 4/2, 25-33.

1985. Theory and practice in philosophical argument. Durban: University of Durban-Westville (The Institute for Social and Economic Research, special publication No 1.)

Richter, P J 1984. Recent sociological approaches to the study of the New Testament. Religion 14, 77-90.

Rodd, C S 1981. On applying a sociological theory to Biblical studies. Journal for the $S$ sdy of the Old Testament 19, 95-106.

Schlier, H 1977. Der Römerbrief. Basel: Herder (Herders theologischer Kommentar zum Neuen Testament.)

Schöllgen, G 1988. Was wissen wir über die Sozialstruktur der paulinischen Gemeinde? New Testament Studies 34, 71-82.

Scroggs, R 1988. The sociological interpretation of the New Testament: The present state of research. New Testament Studies 26, 164-179.

Sklovskij, V 1966. Theorie der Prosa. Herausgegeben und aus dem Russischen übersetzt von Gisela Drohla. Frankfurt: Fischer Verlag.

Sperber, D \& Wilson, D 1986. Relevance: Communication and cognition. Oxford: Basil Blackwell.

Swartley, W M 1994. Israel's scripture traditions and the Synoptic Gospels: Story shaping story. Cambridge, Massachusetts: Hendrikson.

Theissen, G 1978. Sociology of early palestinian Christianity, translated by J Brown. Philadelphia: Fortress.

1988. The social setting of Pauline Christianity: Essays on Corinth. Philadelphia: Fortress Press.

Todorov, T 1966. Die semantische Anomalien, in Ihwe 1971:359-383.

Watson, F 1986. Paul, Judiasm and the Gentiles: A sociological approach. Cambridge: Cambridge University Press. 
Watts, J D W 1987. Isaiah 34-66. Waco: Word Books. (Word Biblical Commentary, Volume 25.)

Weinrich, H 1976. Semantik der Metapher. Folio Linguistica 1, 3-17.

Wilkens, U 1977. Der Brief an die Römer, 1 Teilband, Rm 1-5. Köln: Benziger Verlag. 